\title{
THE EFFECT OF TRADE AND FOREIGN DIRECT INVESTMENT ON EMPLOYMENT AND RELATIVE WAGES
}

\author{
Robert E. Baldwin
}

Working Paper No. 5037

\section{NATIONAL BUREAU OF ECONOMIC RESEARCH 1050 Massachusetts Avenue \\ Cambridge, MA 02138 \\ February 1995}

This paper is part of NBER's research programs in International Trade and Investment, and Labor Studies. Any opinions expressed are those of the author and not those of the National Bureau of Economic Research.

(C) 1995 by Robert E. Baldwin. All rights reserved. Short sections of text, not to exceed two paragraphs, may be quoted without explicit permission provided that full credit, including (C) notice, is given to the source. 


\title{
THE EFFECT OF TRADE AND FOREIGN \\ DIRECT INVESTMENT ON EMPLOYMENT \\ AND RELATIVE WAGES
}

\begin{abstract}
This paper summarizes and assesses recent studies on the impact of current trends in trade and direct investment on employment and wages in OECD countries. The general conclusion is that such factors as changes in labour supplies, technology and demand are more important than changes in trading patterns in accounting for changes in employment and shifts in relative wages. However, further studies are needed to understand better the employment and wage impact of foreign direct investment.
\end{abstract}

Robert E. Baldwin

Department of Economics

1180 Observatory Drive University of Wisconsin

Madison, WI 53706

and NBER 


\title{
THE EFFECTS OF TRADE AND FOREIGN DIRECT INVESTMENT ON EMPLOYMENT AND RELATIVE WAGES
}

\author{
Robert E. Baldwin
}

Recent developments in the international economy have sparked new concerns among OECD policy-makers about the effects of international trade and foreign direct investment on domestic employment and wages. One is the growing trade deficits with a number of newly industrializing countries, especially in manufactured goods, in the face of high unemployment levels and low growth rates of employment and real wages. This has given rise to the fear that jobs are being "siphoned" out of many highly industrialized countries by "catching up" economies (OECD, 1994). There is also concern that the high share of comparatively low skill-intensive products in these imports may be an important contributory factor to the decline in several advanced industrial nations since the 1980 s of the wages of workers with a high school (or less) education relative to those who have attended college. High rates of foreign direct investment by companies from advanced industrial nations in the manufacturing sectors of the industrializing nations are exacerbating these apprehensions about job losses and declining wages.

An institutional development contributing to these anxieties is the negotiation of special regional agreements between certain advanced and developing countries. For example, most U.S. and Canadian labor leaders fear that the North American Free Trade Agreement will cause significant layoffs in the United States and Canada as production facilities in laborintensive industries move to Mexico to take advantage of the lowered trade and investment barriers. The possible accession to the European Union (EU) of countries from Central and 
Eastern Europe has raised similar worries in Europe.

This paper considers the economic evidence that has given rise to these various concerns (Part I); explores the relationships suggested by economic analysis between changes in trade and foreign direct investment and changes in employment and wages (Part II); examines the results of recent studies of the employment impact of trade and foreign direct investment(Part III); evaluates in terms of standard trade theory the empirical evidence concerning the role of trade and other factors in accounting for the observed changes in relative wages in recent years (Part IV); and concludes with a summary of the analysis. (Part V).

\section{Changes in Employment, Trade, Investment, and Relative Wages}

\section{A. GNP and Employment Growth and Unemployment Levels}

GNP and employment growth in the industrial countries picked up after the 1982-83 recession compared to the 1970 s, but slowed again in the early 1990s. Annual GNP and employment growth averaged 3.7 percent and 1.8 percent, respectively, from 1984-1989 in contrast to 3.0 percent and 1.4 percent during the period, 1972-1981 (International Monetary Fund, 1990). However, annual increases in GNP and employment averaged only 1.5 percent and 0.1 percent, respectively, in the industrial countries over the period, 1990-1993. The record on unemployment is also discouraging. From an average unemployment rate of over 8 percent in the industrial countries during the $1982-83$ recession, the rate had declined to 6.5 percent by 1989 but then rose to 8.3 percent by 1993 . The unemployment rate from $1972-81$ averaged only 4.8 percent.

\section{B. Changing Trade Patterns}


In periods of sluggish growth and high unemployment rates, political leaders and various domestic pressure groups typically begin to consider whether shifts in the structure of international trade and investment are part of the cause of their economies' unsatisfactory performance and whether changes in government trade and investment policies might help restore better economic conditions. One such shift that has attracted much attention is the increasing importance of developing countries as suppliers of manufactured goods, especially to OECD countries. Their share of world exports of manufactures rose from 9.7 percent in 1980 to 13.1 percent in 1985 and to 15.8 percent by 1990 , while the OECD share of manufacturing exports declined at an annual rate of .5 percent during the 1980s (International Trade, GATT, various annual issues and OECD Secretariat). These trends have continued in the early 1990s (OECD Secretariat). While the developed countries still had an export surplus of $\$ 85$ billion in manufactured goods with the developing countries in 1989 , the surplus was $\$ 170$ billion in 1980. (If Japan, which experienced an increase in its export surplus with developing countries in manufactures between these years, is excluded from the calculations, the export surplus of the rest of the OECD falls from $\$ 122$ billion in 1980 to $\$ 27$ billion in 1989.)

Significant trade deficits in manufactures have also developed between some rapidly industrializing nations and certain OECD countries. For example, the trade deficit of the member countries of the EU in manufactures with Asia (excluding Japan) rose from $\$ 14$ billion in 1980 to $\$ 36$ billion in 1990 , while the U.S. manufacturing trade deficit with this region increased from $\$ 11$ billion to $\$ 43$ billion between these years. However, the trade deficit of the OECD countries as a group with the so-called "Dynamic Asian Economies" 
(South Korea, Taiwan, Hong Kong, and Singapore) plus China is still small, equalling only .06 percent of their combined gross domestic product (GDP) in 1992.

The EU still had a world trade surplus of $\$ 74$ billion in manufactures in 1990 , but this figure was down from $\$ 96$ billion in 1980 . However, over the decade, the United States shifted from a surplus in manufacturing of $\$ 22$ billion to a deficit of $\$ 84$ billion. In contrast, Japan's trade surplus in manufactures increased from $\$ 98$ billion in 1980 to $\$ 175$ billion in 1990. A very large overall merchandise trade deficit also developed in the United States during the 1980 s. This deficit rose from $\$ 25$ billion in 1980 to a peak of $\$ 160$ billion in 1987 , and still stood at $\$ 108$ billion in 1990 . In contrast, the overall trade deficit of the EU fell from $\$ 84$ billion to $\$ 61$ billion over the decade, while Japan's trade surplus rose from $\$ 11$ billion to $\$ 52$ billion. The members of the European Free Trade Area (EFTA) experienced a shift from a merchandise deficit of $\$ 14$ billion to a surplus of $\$ 5$ billion over the period, while the trade surplus of "other developed countries" declined slightly from $\$ 15$ billion to $\$ 13$ billion.

\section{Changing Direct Investment Patterns}

Inward and outward direct investment flows have also become matters of increased concern to policy-makers in most OECD countries in recent years: inward investment because of the fear that foreigners are gaining too much economic control over the country; outward investment because of the belief that it means the loss of domestic jobs. From the end of World War II until the 1980s, the United States was the largest direct investor in absolute terms, with investment by this country accounting for 44 percent of all OECD direct investment in the period, 1971-1980. ${ }^{\prime}$ There was a virtual explosion of direct investment by 
OECD countries in the 1980 s with outward flows increasing by 220 percent and inward flows by 308 percent. Direct investment by both Japan and the United Kingdom exceeded that by the United States in this decade, as the U.S. share of total OECD outflows declined to only 15 percent. Whereas outward investment was 2.4 times larger than inward investment in the United States in the 1970s, outward investment in the 1980 s was equal to only 40 percent of inward investment in the period.

The importance of the United States as a host country increased significantly in the 1980s. Its share of inward investment flows in OECD countries rose from 30 percent in the 1970 s to 46 percent in the 1980 s. A large part of this foreign investment represented mergers and acquisitions rather than new greenfield projects. The share of acquisitions in the total inflow of direct investment in the United States rose from 67 percent in the first half of the 1980 s to 80 percent in the latter half.

The other major OECD recipient of direct investment traditionally has been the United Kingdom whose share was 21 percent in the 1970 s and 16 percent in the 1980 s. Direct investment in Japan by other OECD countries amounted to less than 1 percent of total investment flows into OECD countries in the 1970 s and actually fell slightly to .4 percent in the 1980s. However, there was an overall shift toward more intra-OECD direct investment, and the developing countries' share of OECD direct foreign investment declined from about one-quarter to one-fifth from the late 1970 s to the late 1980 s.

As Wells (1992) and Oman (1994) emphasize, an important feature of the pattern of foreign direct investment in the 1980s was its regional nature. Production facilities established by multinational corporations in a particular region tended to supply markets in 
that region. Wells presents data indicating, for example, that, in 1989,92 percent of the exports from U.S.-owned firms in Canada went to other countries in the Western hemisphere, and 79 percent of the exports from U.S.-owned firms in Europe were imported by other European countries. While only 35 and 31 percent of the exports from U.S.-owned firms in Japan and in Other Asia/Pacific countries, respectively, remained in the Asia/Pacific region in 1989 , these proportions were significantly higher than in 1982.

The finding that the pattern of foreign direct investment in the $1980 \mathrm{~s}$ was aimed at supplying regional markets, as it had been in earlier years, was somewhat unexpected by many investigators. The rapid growth in developing countries of foreign-owned production facilities supplying labor-intensive intermediate goods led many to believe that a new global structure of production was emerging. Under this arrangement, the various components of final products would be produced in those countries whose factor endowments were best suited for making them, and then shipped around the world to the countries undertaking the assembly activities. The most important factor that has worked against this outcome, according to Oman (1994), has been the coming-of-age of so-called "lean production", the new system of industrial organization that emphasizes the importance of flexibility and continuous innovation, not only in the production process itself but in the product mix and product features. Since this system requires manufacturers to be physically close to their suppliers of parts and components and also to their customers, a regional rather than global system of production by multinational firms has developed.

Another important feature of foreign direct investment in the 1980s was the change in its sectoral composition. A greater share went into service sectors like finance and trade- 
related services, with relatively less flowing into mining and manufacturing. By the mid1980s about 40 percent of total foreign direct investment was in services, as compared with only 25 percent in the early 1970 s. This increase in the importance of services has continued in the early 1990s.

The growth in both outward and inward OECD foreign direct investment declined significantly in 1991 and 1992. Outflows from this group of countries declined by 55 percent between 1990 and 1991 and by another 8 percent between 1991 and 1992. Similarly, inflows dropped by 43 percent between 1990 and 1991 and fell a further 11 percent between 1991 and 1992. Surprisingly, however, outflows from the United States increased sharply between 1991 and 1992. In that year (and also in 1991) U.S. direct investment outflows exceeded inflows, thus restoring the traditional pattern that had been reversed in the $1980 \mathrm{~s}$. It is too early to determine whether these various changes in the early 1990s are due mainly to the recession in most OECD countries or represent a new trend in patterns of foreign direct investment.

\section{Changes in the Pattern of Relative Wages}

OECD policy officials have been concerned about the employment-displacing impact of shifts in the patterns of trade and direct investment since at least the 1970s, and the Organization has undertaken studies in the past on this subject. ${ }^{2}$ However, they have also been concerned in recent years about the increasing wage inequality in a number of OECD countries. An OECD study shows that inequality increased in 12 of 17 member countries during the 1980 s, whereas in the 1970 s inequality generally decreased or remained stable (OECD, 1993b). The increases in inequality in the 1980s were generally small except for the United States and the United Kingdom. Table 1, which is from a study by Katz, Loveman, 
and Blanchflower (1992), presents data on wage inequality for these two countries as well as for France and Japan. As the table indicates, the log wage differential between the 90 th and 10th percentile male workers in the United States increased from 1.23 to 1.40 between 1979 and 1990 or by 17 percent. The same differential for female U.S. workers rose by 31 percent between the same years. Comparable increases in inequality occurred in Great Britain over these years. Inequality also increased in France and Japan but much less than in the United States and Great Britain. (The differential between female and male workers narrowed significantly in most of these countries in the 1980s.) Steven Davis (1992) shows that the wage differential between the 90 th and 10th percentile workers also increased appreciably in Canada in the 1980s. In contrast, Davis finds that wage inequality declined in the 1980 s for such middle-income countries as South Korea, Venezuela and Columbia. It remained about the same for Brazil.

The differential between the highest and lowest paid male workers also increased in the 1970 s in both the United States and Canada, although not as rapidly as in the 1980s. (See Davis). However, inequality declined somewhat in the earlier decade in Great Britain and remained unchanged in France.

Changes in wage differentials among workers with different levels of education and years of work experience provide additional information about shifting wage patterns. As Table 2 indicates, there were moderate to very large declines in the returns to education in the 1970 s in all the advanced countries listed in the top panel of the table. However, as the middle panel indicates, while educational differentials remained flat in Japan in the 1980s, they rose moderately to rapidly in all the other industrial countries listed, except the 
Netherlands. In contrast, educational differentials decreased in the 1980 s in the four middleincome countries listed in the lower panel of the table.

Analysis of more recent U.S. data indicates that there has been a slowing down in the rate at which the differential between the earnings of high school graduates and those with at least some college education has been widening (see Baldwin and Cain, 1994). The gap between the weekly wages of white males with a high school education, i.e., 12 years of schooling, and those with 13-15 years of schooling remained the same between 1987 and 1993, while the gap between white males with a high school education versus those with 16 or more years of education increased only about one-third as much as between 1979 and 1987. However, the rate at which the wage differential between white males with 1-8 years of education and those with 12 years widened between 1987 and 1983 increased compared to the period between 1979 and 1987.

Age-earning differentials moved significantly in favor of older workers during the 1980s in all the advanced countries for which data are available, except Sweden where the differential remained unchanged (see Davis, 1992). Where data are available, the increase in returns to experience seems to date from the late 1960 s to mid-1970s. The record for middleincome countries is less clear. The earning differential between older and younger men increased in Brazil between the mid-1970s and mid-1980s but decreased in South Korea.

Policy officials are concerned about the causes of these shifts. Are they due to domestic factors, such as the discovery of new labor-saving technologies, changes in the relative supplies of more skilled versus less skilled workers, and shifts in tastes, or are they associated with international developments, such as the "catching-up" process that developing 
countries are going through?

\section{The Economics of Changes in Trade, Direct Investment, and Relative Wages}

Standard economic analysis concludes that changes in a country's pattern of trade or direct investment affect its aggregate level of employment only temporarily. In the long-run, macroeconomic factors operate to bring employment to the level where unemployment is at its so-called "natural rate", the rate determined by various structural features of an economy, such as the demographic composition of the work force, the degree of wage flexibility, the minimum wage level, the extent of product-market competition, and the generosity of various social welfare programs.

Starting from a point where unemployment is at its "natural" rate and the balance of payments is in equilibrium, consider, for example, the effects on aggregate employment of a unilateral reduction in a country's tariffs. This policy change tends to increase the country's imports relative to its exports as foreign goods become relatively cheaper. In an economy with a fixed exchange rate where money wages tend to be rigid in the short-run due to the existence of overlapping wage contracts, the switch toward foreign goods and the resulting trade deficit cause a reduction in income and employment levels in the country. Furthermore, if the monetary authorities do not act to offset the decrease in the money supply brought about by the deficit, interest rates will rise, leading to a fall in domestic investment which, in turn, will reduce income and employment even further. However, as wage contracts expire and are renegotiated, the existence of the larger pool of unemployed workers acts to reduce money wages relative to prices, i.e., real wages decline. This causes firms to increase employment as their unit costs fall and profits increase. The balance of trade also improves 
as domestic prices fall relative to foreign prices. The adjustment process continues until the "natural" rate of unemployment is restored and the balance of payments is again in equilibrium. To the extent that exchange rates are flexible, a depreciation of the country's currency in response to the initial deficit tendency facilitates the return of employment to its initial level.

Although there is abundant evidence from OECD countries' experiences with business cycles in the post-World War II period that this macroeconomic adjustment process generally tends to correct for both less-than-full employment and over-full employment conditions, the lengthiness of the process often leads to calls for policy actions aimed at mitigating the adverse consequences of the disequilibrium situation or designed to prevent the economic shock leading to this condition. Furthermore, the persistence of high unemployment rates in a number of OECD countries over the last two decades, especially in Europe, suggests that the "natural" rate of unemployment has risen in some countries. Thus, policy officials are understandably concerned with the employment effects of such international economic shocks as shifts in the volume and composition of trade and foreign direct investment and significant changes in exchange rates.

Whereas economic analysis indicates there are strong forces tending to restore employment to its "natural" level after an economic shock disturbs this condition, no such parallel exists when it comes to shocks that cause changes in relative wages. There is no "natural" relative wage pattern to which an economy tends to return through market forces after relative wages have been changed by some exogenous economic shock. A country's structure of wages depends on such factors as the nature of its technology, factor endowments, 
domestic and foreign preferences for goods and services, institutions, and public policies relative to other countries.

The factor-proportions theory of international trade focuses, for example, on crosscountry differences in relative factor endowments as the cause of trade and determinant of relative factor prices and assumes that technology and tastes are similar among countries. Factors that are relatively scarce in a country will be relatively expensive in the absence of trade, while those that are relatively abundant will be comparatively cheap. Thus, the wages of skilled workers will be high relative to those of unskilled workers if the country's supply of skilled labor is scarce relative to other countries and its supply of unskilled labor is relatively abundant. These conditions give the country a comparative cost advantage in goods that intensively use unskilled labor and a comparative disadvantage in skill-intensive goods, and it will, on average, export the first type of goods and import the other. This pattern of trade will, in turn, tend to bring the structure of relative wages and other factor prices closer together across countries. ${ }^{3}$ Researchers, e.g., Barro (1991), and Mankiw, Romer and Weil (1992), have found evidence of income convergence among the OECD countries.

In contrast, the Ricardian trade model emphasizes relative differences in technology across commodities as the cause of differences among countries in comparative costs and in relative factor prices. Suppose, for example, that a country's relative factor endowments are no different than the rest of the world but that its technology gives the country a productivity advantage in producing skill-intensive goods. Since in the absence of trade, these goods will be relatively cheaper in the home country than in the rest of the world, they will be exported as trade is opened up. This, in turn, tends to raise the wages of skilled relative to unskilled 
workers in the home country, while having the opposite effect in the rest of the world.

The nature of institutions, preferences, and public policies also plays a significant role in determining the structure of relative wages and other factor prices. For example, the degree of unionization among various skill groups and the minimum wage level imposed by the government obviously affect relative wages. Similarly, the magnitude of resources that a country devotes to higher education and its propensity to save have important implications for the pattern of factor prices evolving over time.

III. Evidence on the Short-Run Employment Impact of Changing Trade and Investment

\section{Patterns}

Even though unemployment may tend to return in the long-run to its so-called "natural" rate after exogenous shocks, political leaders are still very concerned about the shortrun employment effects of such shocks, since they can cause significant adjustment problems. Changes thought, rightly or wrongly, to be related to trade and foreign direct investment seem to be of special concern due to traditional xenophobia as well as the fear that international factors, over which domestic policy officials have little control, may have a significant adverse impact on domestic welfare.

\section{A. Trade and Employment}

Several studies have investigated the output and employment impact of shifts in the volume and composition of trade, especially the trade of developed with developing countries. ${ }^{4}$ The general finding of these inquiries is that the net employment effects of changes in exports and imports have not been significant in OECD countries. ${ }^{5}$ However, a second conclusion is that trade changes have produced significant adverse employment effects 
in particular industries, especially labor-intensive sectors such as textiles, clothing, timber, furniture and leather. Four recent studies are discussed below and the results of a selected set of studies are summarized in Table 4.

i) $\underline{\operatorname{OECD}(1992 b)}$

A recent $O E C D$ study analyzes the relative importance of various structural factors in explaining employment changes in several member countries during the 1970s and early 1980 s. $^{6}$ It uses input-output techniques to decompose changes in output and employment by industry in nine OECD countries, namely, Australia, Canada, Denmark, France, Germany, Japan, the Netherlands, the United Kingdom, and the United States. The sources of structural change identified are: shifts in structure associated with domestic final demand, exports, imports of final products, imports of intermediate products, technical change, and, in the case of employment, labor productivity. Among the unique features of the study are its relative fine level of industry detail (33 separate industries), the inclusion of the service sector, the division of the manufacturing sector into high-wage, medium-wage and low-wage industries, and the breakdown of exports and imports by region.

Of particular interest for the issues being considered in this paper is the study's decomposition of average annual percentage changes in total employment in seven of the nine countries, usually from the early 1970 s to the mid-1980s (see Table 3 ). ${ }^{7}$ The first point to note in the table is the positive employment impact from trade (exports minus imports) in most countries for most of the various periods covered. The United Kingdom is an exception, however, with the employment-displacing effect of import expansion exceeding the jobcreating effect of export expansion for all the periods covered. In the United States the job- 
creating effect of increased exports exceeded the job-displacing impact of greater imports both between 1972 and 1977 and between 1977 and 1982, but.the net job-displacing effect from trade between 1982 and 1985 was significant enough to produce a negative job effect for the entire 1972-1985 period. It was during this latter period, of course, that the dollar appreciated sharply, thereby leading to large U.S. trade deficits.

When trade in manufactured goods is considered separately (not shown), the net impact of trade over the entire period covered in each country was negative for four of the seven countries, namely, Canada, France, the United Kingdom and the United States. Furthermore, within the manufacturing sector, trade in the products of low-wage industries, namely, food, beverages, and tobacco; textiles and apparel; wood and cork products; electrical machinery other than communications equipment; other transport equipment besides aircraft and motor vehicles; and miscellaneous manufactures, was most likely to have a net negative effect on employment.

Another relationship evident from Table 3 is that changes in final demand for domestic goods (the increase in total final domestic demand minus the increase in imports) generally had a much greater effect on employment than changes in domestic demand for imported goods. Increases in labor productivity also generally displaced significantly more jobs than increases in imports.

The breakdown of exports and imports by region indicates that trade with the Dynamic Asian Economies (South Korea, Taiwan, Hong Kong and Singapore) plus China had a small negative output impact on most countries (Japan and France were exceptions). Analysis of individual sectors shows the service and government sectors to be the most 
rapidly growing areas in employment terms, with employment in manufacturing decreasing in most of the countries. Within the manufacturing sector, employment grew the most rapidly (or decreased the least) in high-wage industries compared with medium-wage and low-wage industries.

The decomposition approach, using input-output analysis, has been criticized on several grounds, ranging from the absence of any behavioral content, the static nature of the analysis, the assumption of fixed input-output and labor coefficients, and the failure to introduce the effects of scale economies. ${ }^{8}$ Obviously, the various components of the decomposition of employment effects are not independent of each other. For example, increases in labor productivity tend to increase both domestic final demand and exports. Another linkage that has been emphasized (see Martin and Evans, 1981 and Wood, 1993) is between imports and productivity changes. It has been argued that actual or threatened import competition will cause producers to rationalize production facilities, invest in labor-saving techniques and shed labor. However, the decomposition formula will attribute the decline in the use of labor to productivity changes without recognizing that these productivity changes may have been the result of import competition.

Although this line of reasoning recognizes that technical progress can be an endogenous as well as exogenous process, the link between imports and productivity growth in existing endogenous growth models is not as direct as postulated in the above analysis. In these growth models, individual producers undertake those R\&D activities that maximize their profits. An increase in actual or threatened import competition affects R\&D efforts only by changing economic variables that influence profits. For example, an increase in import 
competition in a sector, by decreasing the price of the import-competing domestic good, tends to decrease the profitability of investments in knowledge in the sector and thus lower the rate of productivity growth. Furthermore, an increase in unskilled labor-intensive imports tends to lower the price of unskilled labor in the importing country and raise the price of more highly educated labor. If, as is usually assumed, $R \& D$ activities are intensive in their use of highly educated labor, this increase in the price of such labor tends to have the effect of lowering the rate of technical progress, thereby lowering the rate of growth in labor productivity. Both these lines of reasoning produce conclusions opposite to the one mentioned above. However, by increasing the exchange of information among producers, increased trade can have the effect of reducing duplication of research efforts and, by thereby increasing the aggregate productivity of resources employed in $R \& D$, raising innovative activities.

The so-called X-efficiency literature does, however, provide an analytical basis for why increased import competition might lead to managerial actions that raise labor productivity and reduce employment (see Leibenstein (1966), Corden ( 1974), Caves and Krepps (1993)). The idea behind this concept is that managers, especially those in oligopolistically organized product sectors, do not take all actions to maximze profits, for such reasons as a preference for leisure over the work involved in seeking out all profitable opportunities and the power and satisfaction they gain from an excess number of employees. However, given some rent-threatening disturbance, such as increased international competition or a shift in corporate control, managers take actions to increase efficiency by eliminating excess labor or possibly by introducing labor-saving techniques that were not fully exploited prior to the competitive disturbance. The extent to which this type of inefficiency within 
firms actually exists and can be eliminated by increased competition is still a matter of considerable disagreement among economists. More empirical tests of the X-efficiency hypothesis and a more fully specified theoretical model of managerial behavior in various market structures seem needed to establish a general connection between increased import competition and productivity growth.

ii) Driver, Kilpatrick and Naisbitt (1988)

Two recent criticisms of the conclusions of the decomposition approach, in which the authors have provided empirical estimates of the effects of introducing alternative assumptions, deserve particular attention. The first by Driver, Kilpatrick and Naisbitt (1988) involves the criticism that typical estimates of the employment impact of structural changes are based on average labor coefficients of broad industrial sectors that are usually each composed of many firms with very different levels of labor productivity due, for example, to differences in age and location. ${ }^{9}$ As the authors note, an expansion in demand is likely in the short-run to lead to the reinstatement of low-productivity (high labor coefficient) equipment that had been mothballed. A decline in the demand is also likely to result in the idling of the least productive equipment. In contrast, a sustained increase in demand will probably be met by installing new equipment, which is likely to have a higher labor productivity (lower labor coefficient) than existing facilities.

To estimate labor coefficients based on the most and least productive firms in an industry, the authors utilize data from the National Economic Development Office of the United Kingdom that provides a distribution of output per worker for each U.K. manufacturing industry. They specifically estimate output per worker (inverted to obtain 
employment per unit of output) for the first and third quartiles of the output distribution for each industry as well as the average productivity for each industry. They then calculate the employment effects of a balanced 100 million pound increase in U.K. exports and imports based on 1979 trade shares under three different assumptions. The first uses average labor coefficients to calculate employment changes, while the second uses industry labor coefficients based on the least productive workers producing one-quarter of the industry's output. The third scenario utilizes the latter coefficients to measure the import displacement but uses labor coefficients based on the most productive workers producing one-quarter of the industry's output to measure the employment generated by exports..

Under the first assumption they find that a balanced 100 million pound increase in UK exports of manufactured goods to developing countries and imports of manufactures from these countries results in a net employment loss of 1314 jobs, whereas under the second and third senarios, the net job losses are 1445 and 5,227, respectively. Similarly, a 100 million pound expansion of UK exports and imports to and from other EC countries causes a loss of 3,514 jobs based on the third set of assumptions, but only 223 jobs when average labor coefficients are utilized.

The authors may be correct in concluding that the usual method of estimation understates the employment impact of trade changes. But, before their approach can be accepted, empirical tests of their hypothesis concerning the relative efficiency of firms supplying most of the goods when exports increase and those most affected by import increases need to be undertaken by analyzing firm-level data for various industries.

iii) Wood $(1991,1994)$ 
Wood (1991 and 1994) also criticizes the usual manner by which labor coefficients are calculated when estimating the employment effects of trade with developing countries. He argues that many manufactured imports from developing countries (the South) are noncompeting imports, in the sense of not being produced in the developed countries (the North). They are not produced in the North because their high unskilled labor intensity makes them unprofitable. (The manufactured imports of the developing countries are also largely noncompeting, in the sense of not being produced in the developing countries.) $\mathrm{He}$ argues, therefore, that it is inappropriate to use the labor coefficients of the developed countries in estimating the employment that would be generated in these countries if they produced their imported manufactures.

The alternative procedure followed by Wood is to construct a set of counterfactual labor coefficients by starting with the actual average labor and capital coefficients used in producing the South's exports of noncompeting manufactures (taken to be all manufactures except processed primary products). On the basis of factor price estimates for unskilled labor, skilled labor, and capital in the manufacturing sectors of the South and North and estimates of factor substitution elasticities, he then modifies the South's coefficients to take account of the North's different relative factor prices. This yields the the unskilled labor, skilled labor and capital coefficients needed to produce the noncompeting manufactures in the North. Finally, Wood takes account of the point that the costs and thus prices of these manufactures would be more expensive in the developed countries due to their higher factor prices. Thus, the increase in labor-intensive manufactured output volume of the North would be smaller than the actual volume of imports. 
On the basis of these various adjustments, Wood estimates that the employment content of imports of manufactures by the North from the South exceeds the employment content of exports by the North to the South by about 9 million person-years or by about 12 percent of actual employment in Northern manufacturing. In contrast, he estimates the difference to be only about 1 million person-years when the conventional method of using the North's labor coefficients is followed. Moreover, he argues that the difference would be considerably larger if one took into account the labor-saving technological progress stimulated in the North in reaction to competition from the South.

A number of points arise concerning Wood's approach. The most obvious one relates to his contention about the importance of noncompeting manufactures in North-South trade. In his empirical analysis, he assume that all manufactures other than processed primary manufactures, such as food and refined petroleum, are noncompeting. While one can readily agree there are many goods imported into the United States, for example, that are not produced in the country, to assume that all manufactures other than process primary products are noncompeting seems a considerable exaggeration.

Wood cites two sources to support this assumption. The first is a theoretical paper by Krueger (1977), in which she develops a model where factor-price equalization does not prevail and countries produce manufactured goods that, in general, require inputs similar to their overall capital/labor ratios in manufacturing. The second is a series of developing country studies on trade and employment directed by Krueger (Krueger, Lary, Monson, and Akrasanese, 1981; Krueger, 1982; and Krueger, 1983). Utilizing the theoretical framework of Krueger's 1977 paper, these studies investigate the contribution to domestic employment of 
import-substitution versus export-oriented trade policies. Thus, they involve estimating domestic labor coefficients for goods that are exported, goods that are imported but also produced domestically, and imported goods that, while not currently produced domestically, might be produced locally under further import-substitution policies.

Each investigator was left to determine which goods fitted the last category (noncompeting imports), based on his special knowledge of the economy, but the general rule followed was to consider imports as noncompeting if the ratio of (consumption - domestic production)/ consumption in the industry in which the imports were classified was between .5 and .99. The considerable differences among the investigators in the value of this ratio selected as indicating the existence of a non-import-competing sector and the wide difference among the countries in the calculated shares of noncompeting imports, e.g., Chile with $22 \%$, Thailand with $44 \%$, and Pakistan with $72 \%$, suggest that the calculations were highly dependent on the investigators' individual judgements as to what should be regarded as a noncompeting import. The ratio is also only a very crude test of whether imports are noncompeting or not. However, since the countries studied were in the early stages of industrialization, it is not surprising that some investigators found relatively high ratios of noncompeting imports of manufactured goods to total manufacturing imports. In contrast, in mature industrial countries like the United States and most EU countries, one would expect to find considerably lower ratios of imports of noncompeting manufactured goods to total imports.

One source of evidence on this latter conjecture comes from input-output tables compiled by most governments. The builders of these tables have long had to deal with the 
issue of whether a particular imported good is substitutable for some domestically produced good or not. In the U.S. input-output tables for 1977 and $1982,14.4$ percent and 13.9 percent, respectively, of total imports are classified as noncompeting (U.S. Department of Commerce, 1984 and 1988). This suggests that one needs considerably more evidence on the importance of noncompeting products before Wood's assumption can be accepted as realistic. ${ }^{10}$

Wood also assumes, as did Krueger, that the state of technology is the same in the South and North. However, if the productivity of labor and capital is considerably higher in the North than the South due to access to better technology and managerial practices, Wood's method exaggerates the labor needed in the North to produce domestically the manufactured goods imported from the South. There is considerable empirical support for the view that significant productivity differences exist between developed and developing countries. ${ }^{11}$ An alternative to Wood's methodology for calculating labor coefficients for goods no longer produced in the developing countries, e.g., black and white TV sets or simply manufactured footwear, that could be used to check on the empirical importance of this point would be to begin with the factor coefficients that prevailed in the North at the time this group of countries produced the manufactures that are now noncompeting. These coefficients could then be modified to take account of changes in relative factor prices in the manner followed by Wood. ${ }^{12}$

iv) Berman, Bound and Griliches (1994)

This paper is also relevant for assessing the impact of international trade on employment. These authors attempt to explain the causes of the observed shift away from unskilled and toward skilled labor in U.S. manufacturing in the 1980s. In particular, they 
consider the relative importance of the following shocks: unskilled labor-saving technological progress, an expansion of international trade that has resulted in a decrease in the demand for unskilled workers and an increase in the demand for skilled workers, and an increase in Defense Department procurements that has had a similar effect. Their main data source is the U.S. Annual Survey of Manufactures, which provides information about the use of production and nonproduction workers in four-digit SIC industries. This classification of workers closely mirrors the distinction between blue-collar and white-collar occupations, as well as between those who do not have a high school education and those who do.

Utilizing skill indexes based on the relationship between hourly earnings and occupations of blue-collar and white-collar workers, Berman et al. first show that a significant part of the skill upgrading between 1973 and 1987 was due to an economy-wide shift to white-collar or nonproduction labor. They then decompose the increase in the proportion of nonproduction workers in the economy into that part due to their increased use within industries and that part due to the shift in production toward industries using high proportions of such workers. The authors argue that the increase in U.S. trade in manufactures as a share of manufacturing shipments and the military build-up both work primarily by shifting the derived demand between industries from those intensive in production workers to those intensive in nomproduction workers. In contrast, they argue that biased technological change shifts the skill composition of labor demand within industries.

Berman et al. find that the within-industry component dominates the between-industry component. For example, of the .552 percentage points per annum increase in the nonproduction share of manufacturing employment between 1979 and 1987, the within- 
industry component accounts for .387 percentage points or 70 percent and the betweenindustry for .165 percentage points or 30 percent. In the period, 1973-1979, the withinindustry share is 63 percent.

They also further decompose the between- and within-industry effects in each of the 450 industries into four sectors: domestic consumption, exports, imports, and defense procurement, assuming that imports replace employment in other sectors. Their finding from this analysis is that the contribution of imports and exports to the annual rise in the share of nonproduction workers between 1979 and 1987 due to between-industry shifts, namely, .165, is 29 percent, whereas defense procurement accounts for 44 percent of the shift. Thus, of the total annual increase of .552 percentage points per year in the nonproduction share of manufacturing employment between 1979 and 1987, only 9 percent ([.29x .165]/.552) was due to between-industry shifts in exports and imports. ${ }^{13}$ Thus, they conclude that the role of trade in shifting employment away from production-labor-intensive industries is quite small.

The claim by the authors that the increase in international trade works mainly by shifting the demand for skilled versus unskilled labor among industries whereas biased technological changes primarily affect the demand within industries for skilled versus unskilled labor is not supported by trade theory. The authors do not discuss the reasons why the ratio of a country's exports and imports to its output can increase at unchanged terms of trade but possible reasons are a reciprocal reduction in tariffs among countries or a general decrease in transportation costs. In these situations trade could expand as a share of a country's gross domestic product without any change in the international prices of the two goods. 
To be more specific, consider the standard two-factor (skilled and unskilled labor), two-good (a skilled labor-intensive good and a unskilled labor-intensive good), two-country Heckscher-Ohlin trade model in which one of the countries is exporting the skilled laborintensive good, while the other exports the unskilled labor-intensive good. The endowments of the two factors remain fixed in the two countries. While the reciprocal reduction of tariffs or the decrease in transportation costs need not change the international prices of the two goods, these changes will increase the domestic price of each country's export good (lower the relative price of each country's import good). If we also assume that the labor coefficients are fixed in each country, each country's output levels for the two goods would not change nor would there be any change in the use of skilled versus unskilled labor within each country. However, the real wages of skilled labor would increase relative to the wages of unskilled labor in the country exporting the skilled labor-intensive product and fall in the other country. ${ }^{14}$

If, as is likely to be the case, factor coefficients are not fixed, the output of the skilled labor-intensive good will expand in the country exporting this good, and the output of the unskilled labor-intensive good will decline. The opposite will take place in the other country. At the same time, in response to the change in relative factor prices, there will be a substitution of unskilled labor for skilled labor in the country exporting the skilled laborintensive product, thereby decreasing the ratio of skilled to unskilled labor in the two industries. ${ }^{15}$ The opposite will take place in the other country. Thus, as trade expands, there is both a within-industry shift in the relative use of skilled and unskilled labor and a betweenindustry shift toward either the skilled labor-intensive goods or the unskilled labor-intensive 
product. Both shifts take place concurrently.

These points can be illustrated with the aid of Figures $1 \mathrm{a}$ and $1 \mathrm{~b}$, which depict a country's production, trade and factor allocation in the standard two-good, two-factor Heckscher-Ohlin trade model with constant returns-to-scale and perfect competition. To simplify the analysis, assume that the home country, whose production possibilities curve, TT, is shown in Figure 1a, faces fixed international prices for the two goods it produces, $\mathrm{X}$ and $\mathrm{Y}$. The country is assumed to import good $\mathrm{X}$ and export good $\mathrm{Y}$. The slope of the line $\mathrm{p}_{\mathrm{f}} \mathrm{c}_{\mathrm{f}}$ (equals the slope of the line $p_{t} c_{t}$ ) indicates the international price of good $\mathrm{X}$, while the reciprocal of this slope represents the international price of good Y. Assume that intiially the country imposes a duty on imports of good $\mathrm{X}$ in order to stimulate domestic production of this good. It produces at point $\mathrm{p}_{\mathrm{t}}$ on its production possibilities curve where the marginal cost of producing $\mathrm{X}$ (equals the slope of the production possibilities curve) equals the domestic price of $\mathrm{X}$, which exceeds the international price by the duty. The country trades along the international price line, $p_{t} c_{1}$, to the consumption point $c_{t}$, where the slope of a community indifference curve equals the slope of the production possibilities curve at $p_{1}$. If the home country removes the import duty, production shifts to $\mathrm{p}_{\mathrm{f}}$, as the domestic price of $\mathrm{X}$ falls to equal the international price of $\mathrm{X}$. This stimulate a between-industry production shift that increases the output of $\mathrm{Y}$ and reduces the output of $\mathrm{X}$.

Figure 1b, the so-called Bowley-Edgeworth box diagram, depicts how the allocation of the given supplies of unskilled and skilled labor changes as the production point on the production possibilities curve changes. The size of the box indicates the home country's total supplies of unskilled labor (measured along the $\mathrm{x}$ axis) and skilled labor (measured along the 
$\mathrm{y}$ axis). The amounts of skilled and unskilled labor allocated to the production of good X are measured from the origin $\mathrm{O}_{\mathbf{x}}$, whereas the quantities of skilled and unskilled labor used in producing good $\mathrm{Y}$ are measured from the origin $\mathrm{O}_{\mathrm{Y}}$. All of the endowments of unskilled and skilled labor could be used to produce only good $X$ (the point $\mathrm{O}_{\mathrm{Y}}$ shows this allocation), only good $\mathrm{Y}$ (the point $\mathrm{O}_{\mathrm{X}}$ shows this allocation of the two factors), or various combinations of the two goods (the curve $\mathrm{O}_{\mathrm{x}} \mathrm{p}_{\mathrm{t}} \mathrm{p}_{t} \mathrm{O}_{\mathrm{Y}}$ in Figure $1 \mathrm{~b}$ indicates the maximum amounts of one of the goods that can be obtained for a given level of production of the other). This optimum output expansion curve is the locus of tangencies of the equal output curves of the two goods, where good $\mathrm{X}$ isoquants, $\mathrm{i}_{\mathrm{X}}$, are measured from the origin $\mathrm{O}_{\mathrm{X}}$ and good $\mathrm{Y}$ isoquants, $\mathrm{i}_{\mathrm{Y}}$, are measured from the origin $\mathrm{O}_{\mathrm{Y}}$. Since good $\mathrm{X}$ is assumed to be unskilled labor-intensive (good $\mathrm{Y}$ is assumed to be skilled labor-intensive), the optimum output expansion curve is below a straight line between $\mathrm{O}_{\mathrm{X}}$ and $\mathrm{O}_{\mathrm{Y}}$.

At the tariff production point $\mathrm{p}_{\mathrm{t}}$ in Figure $1 \mathrm{~b}, \mathrm{O}_{\mathrm{x}} \mathrm{X}_{\mathrm{t}}$ of unskilled labor and $\mathrm{X}_{\mathrm{t}} \mathrm{p}_{\mathrm{t}}$ of skilled labor are devoted to the production of good $X$, while $\mathrm{O}_{\mathrm{Y}} \mathrm{Y}_{\mathrm{t}}$ of unskilled labor and $\mathrm{Y}_{\mathrm{t}} \mathrm{p}_{\mathrm{t}}$ of skilled labor are devoted to the production of good Y. In the move to the free trade point, the ratio of skilled to unskilled labor used in producing good $\mathrm{X}$ and the ratio of skilled to unskilled labor used in producing good $\mathrm{Y}$ both decline (or the ratios of unskilled to skilled labor rise), as can be seen in the diagram. It follows that the wages of skilled labor rise relative to wages of unskilled labor in both sectors, since in each sector there are relatively more unskilled workers to assist the skilled workers. Thus, in addition to the betweenindustry shift in the use of unskilled versus skilled labor resulting from the increase in the production of the skilled labor-intensive good $\mathrm{Y}$ and decrease in the production of the 
unskilled labor-intensive good $\mathrm{X}$ as the tariff is removed, there is a within-industry shift toward the relatively greater use of unskilled labor in the production of both goods. This latter shift occurs as producers substitute unskilled labor for skilled labor in response to the relative decline in the wages of unskilled labor.

Unskilled labor-saving technical progress also brings about relative shifts in labor demand among industries as well as within industries. Consider the case where this type of technological progress occurs to the same extent in both industries. Besides the withinindustry shift toward the greater use of skilled compared with unskilled labor in both sectors, the output of the unskilled labor-intensive industry will increase relative to the output of the skilled labor-intensive good. ${ }^{16}$ As long as the country is too small to affect its terms of trade, this output shift will have no additional impact on the use of skilled versus unskilled labor in each sector. However, if the country is "large" in the sense of being able to affect its trading terms, the price of the unskilled labor-intensive good will fall due to the the relative increase in its supply, thereby reducing the relative wages of unskilled workers. Nevertheless, if the labor coefficients are fixed, there will be no further changes in relative outputs. But if substitution among the two factors is possible, these changes will cause the output of the unskilled labor-intensive sector to decline relative to the output of the skilled labor-intensive industry and within-industry shifts toward unskilled labor that will partly offset the shift toward skilled labor due to the technological change. Thus, if factor substitution is possible, both within-industry and between-industry shifts occur as a consequence of technical change. These relationships are explained in more detail with the aid of diagrams A1, A2, A3 and A4 in the Appendix. 
There seems little doubt but that unskilled labor-saving (skilled labor-using) technological progress has taken place to a considerable extent, at least in the United States, in recent years. Between 1977 and 1987, for example, the unweighted average ratio of workers with 13 or more years of education to workers with 12 years of education or less increased from .46 to .61 in the 67 industries of the U.S. input-output table in which international trade in goods or services trade takes place (Baldwin and Cain, 1994). This occurred even though the wages of these two groups moved in the direction that tended to lead to the substitution across industries of less well educated workers for better educated workers, i.e., the ratio of the wages of the former to the latter workers increased from 1.35 to 1.52 between these years (ibid). However, while biased technical progress may have played the dominant role in accounting for the increased share of skilled workers, it is not possible to base such a conclusion on the finding that within-industry shifts in the use of skilled labor relative to unskilled labor have been considerably greater than between-industry shifts. Unskilled labor-saving technological progress, an expansion of international trade, and an increase in Defense Department procurements (the three shocks that the authors consider) all produce both between-industry and within-industry shifts in the relative demand for skilled versus unskilled labor, and it is not possible to state a priori that unskilled labor-saving technical progress works primarily by shifting the demand for skilled versus unskilled labor within industries, whereas the other two shocks mainly have the effect of shifting the between- industry demand for different labor skills.

B. Foreign Direct Investment and Employment

As is the case with trade, there is a wide divergence of views concerning the effect of 
direct investment abroad on domestic employment. Labor unions maintain that there is a loss of actual or potential jobs when firms invest abroad as well as when either exports fall or imports rise. In contrast, multinational firms contend that much of their foreign direct investment is induced by the growing competitiveness of foreign producers and, thus, that domestic jobs would be lost even if they did not invest abroad. Indeed, they contend they are able to maintain domestic employment in high-skill activities by transferring their laborintensive activities abroad. In addition, these firms point to the increased demand by their subsidiaries for domestically-produced intermediate products and capital goods, as direct foreign investment takes place. ${ }^{17}$

The view of most economists seems to be that no firm conclusion is warranted about the net employment effects of direct foreign investment. Broad generalizations are difficult because of the very different employment effects one obtains from various plausible alternative assumptions about what will happen in the absence of foreign investment and what the magnitude of increased imports by the host country from the investing country will be. For example, one well-known study by Bergsten, Horst and Moran (1978) finds that modest levels of foreign direct investment are positively correlated with U.S. exports, while higher levels are less related to exports and may even begin to substitute for them. Lipsey and Weiss (1981) conclude that there generally is a complementary relationship between U.S. foreign direct investment and U.S. exports. In contrast, a more recent study by Glickman and Woodward (1989) concludes there was a net average annual loss of U.S. jobs between 1977 and 1986 of 274,000 as a consequence of U.S. investment abroad or .5 percent of average total U.S. employment over these years. ${ }^{18}$ 


\section{i) Glickman and Woodward (1989)}

The approach followed in deriving these figures is adapted from Frank and Freeman (1978). These two authors utilized a model in which U.S. firms are assumed to possess monopoly power in foreign markets and, therefore, set prices above marginal costs in supplying these markets either by exporting from the home country or producing the goods in foreign subsidiaries. By estimating foreign demand elasticities and ratios of marginal costs (assumed to be constant) in domestic and foreign subsidiary facilities (the latter assumed to be lower than the former) for various industries, Frank and Freeman first derive substitution parameters indicating the ratio of the quantity of goods each industry would supply in the foreign market if it only exported to this market compared to the quantity it would supply in this market if it did not export but produced these goods in its lower cost foreign facilities. They next multiply the estimated volume of subsidiary production in each industry (calculated by multiplying the annual investment expenditures of the industry's foreign subsidiaries by an appropriate capital/output ratio) by these substitution parameters to estimate the export production that is displaced by foreign investment. Finally, the direct and indirect number of jobs displaced by this loss of exports is calculated from the 1970 input-output table and appropriate labor coefficients. The gain in employment due to increased exports of intermediate goods to foreign subsidiaries as a consequence of foreign investment is also estimated utilizing historical data on the exports of intermediates to foreign subsidiaries. These various steps yield an estimate for the net number of jobs displaced by U.S. foreign investment in 1970 of 160,377 .

As Frank and Freeman are aware, this estimate of job losses is very sensitive to their 
estimates of demand elasticities, which are based on accounting costs rather than a measure that includes the opportunity cost of capital. Rousslang (1978, p. 176) maintains that, if an appropriate measure of costs that includes the opportunity costs of capital is used to estimate demand elasticities, the export displacement effect in the Frank-Freeman model is more than offset by the employment stimulus stemming from increased exports of intermediate goods to the subsidiaries. The Frank-Freeman results also differ considerably if marginal costs are assumed to be increasing rather than constant and if competition from other foreign firms is taken into account.

Glickman and Woodward (1989) are aware of these problems but feel they would be too difficult to incorporate in an empirical model, and they, therefore, follow the methodology of Frank and Freeman. However, unlike Frank and Freeman, they do not provide any sensitivity analysis on how their estimates of the net job displacements change with alternative estimates of the substitution parameters nor do they provide information on their estimates of these parameters across industries.

Glickman and Woodward also estimate the employment impact of foreign direct investment in the United States, using a very different methodology. Survey data from the Bureau of Economic Analysis (BEA) of the U.S. Department of Commerce indicate that the number of employees of U.S. affiliates of foreign companies increased by about 547,927 between 1982 and $1986 .{ }^{19}$ For these years, BEA broke down the components of the employment change in large affiliates into five sources: new investments, expansions, sales or liquidations, cutbacks, and combinations of new investments and sales or liquidations of businesses. By making various assumptions, Glickman and Woodward rearrange these 
components into the employment changes due to: new plants $(+45,151)$; expansions

$(+341,281)$; acquisitions $(+1,381,690)$; cutbacks $(-442,295)$; and sales and liquidations

$(-777,900)$. The sum of these components yields the 547,927 figure cited above.

The authors argue that most of the almost 1.4 million job gains under the acquisitions category merely represent the transfer of existing jobs from domestic to foreign owners.

Furthermore, they also note that the sales of assets may not lead to any job losses but just the transfer of existing jobs from domestic to foreign owners. However, they believe that liquidations of assets are more likely to lead to net job losses. Their inability to separate these two components makes it impossible to evaluate the loss of almost 0.8 million jobs cited above in the sales and liquidation component. Glickman and Woodward emphasize that if one looks just at the sum total of new plants, expansions, and cutbacks, there is a net loss of jobs amounting to 55,863 . They do recognize that the years covered include the recession year of 1982 and point out that, if just the period 1984-1986 is used, these three components yield a net job gain of 55,510. Thus, these authors conclude that, at best, the number of new jobs created through direct investment by foreigners in the United States has been modest and may be negative. In any event, they believe any gain to be less than the number of jobs lost by direct investment abroad by U.S. firms.

An unsatisfactory feature of the Glickman-Woodward analysis is the difference in the methodology used to estimate the employment impact of U.S. direct investment abroad and foreign direct investment in the United States. In particular, one would have liked to see an estimate of the U.S. employment impact of direct investment by foreign firms based on the same kind of approach used in estimating the employment effects of U.S. direct investment 
abroad. Expenditures on plant and equipment are available for U.S. affiliates of foreign companies, just as they are for foreign affiliates of U.S. companies. Thus, the increase in output associated with this investment could be estimated, using appropriate capital/output ratios. Furthermore, information from the BEA surveys is available to estimate the imported component of this output. Utilizing the input-output table and appropriate labor coefficients, the direct and indirect employment generated in the United States from the investment expenditures of U.S. affiliates of foreign firms could then be estimated and compared with their estimate of job losses due to U.S. direct investment abroad. Without a comparability exercise such as this, the conclusion of Glickman and Woodward that U.S. investment abroad results in large U.S. job losses, while foreign investment in the United States creates few jobs, cannot be regarded as robust. More research is needed to reach conclusions in which one can have greater confidence about the net U.S. employment impact of U.S. direct investment abroad and foreign investment in the United States.

\section{ii) Other Studies}

Analysis by the OECD Secretariat indicates that net direct investment flows of OECD countries in the period 1980-1990 amounted to only .73 percent of their gross fixed capital formation. Moreover, much of this investment was directed at other OECD countries. Consequently, the numbers simply do not support the view that foreign direct investment has resulted in a massive transfer of job creation possibilities to non-OECD countries. However, this does not mean that there have been no substantial effects for particular sectors or companies.

A recent study by Messerlin (1994) provides additional insights into the relationships 
between foreign direct investment and employment. Using detailed industry data for France from 1989 to 1992, Messerlin finds that direct foreign investment by French firms was concentrated in industries in which he estimates trade changes have brought about job gains rather than in those sectors that experienced job losses through trade.

\section{Evaluation of Empirical Evidence on the Effects of Trade and Other Factors on Relative} $\underline{\text { Wages }}$

Some of the earlier studies cited in Part III not only include calculations of the aggregate employment effects of trade and direct foreign investment but employment estimates by various skill groups. For example, Sapir and Schumacher (1985) [also see Schumacher (1984)] estimate that, although a $\$ 1$ billion expansion of exports and imports of manufactured goods, distributed in the same commodity structure as prevailed in 1977, would decrease aggregate employment in Germany, France, Italy, the United Kingdom, the Netherlands, and Belgium, the demand for skilled labor (salaried employees and skilled workers) would rise in all of these countries except Italy. ${ }^{20}$ Neglecting changes in the supplies of various types of labor, this suggests that the trade patterns of these countries in manufactured goods tended to raise the wages of skilled workers relative to semi-skilled and unskilled workers. Similarly, in their study of the labor-displacing effects of foreign direct investment by the United States in 1970, Frank and Freeman (1978) found that the demand for semi-skilled and unskilled workers decreased relative to that for professional, managerial, clerical and sales workers.

In recent years economists have devoted considerable research efforts to investigating the demand and supply forces that have brought about the observed changes in the relative 
wages of better educated compared with less well educated workers over the last 25 years in advanced industrial countries, especially in the United States, e.g., Katz, Loveman, and Blanchflower (1992); Katz and Murphy (1992); Bound and Johnson (1992); Krugman and Lawrence (1993). Most investigators conclude that factors other than changes in trading patterns account for most of the change in wage differentials in countries such as the United States, the United Kingdom, Japan, and France. They point out that the declining education differential in the 1970s and increasing differential of the 1980s in the United States and the United Kingdom are consistent with steady growth in the demand for highly educated workers over the period, due to skilled-labor-biased technical change, coupled with the rapid increase in the relative supply of highly educated individuals in the 1970s and the slowing down in this supply during the 1980s (Katz, Loveman, and Blanchflower, 1992, p.27). They also stress the importance of differences in labor market institutions, especially the influence of labor unions and minimum wage levels established by the government, in explaining the observed shifts in wage differentials. However, some investigators believe that changes in the structure of international trade, especially those related to the appreciation of the dollar, were an important factor in accounting for relative wage shifts in the United States during the 1980 s. $^{21}$

Three recent studies analyzing how the changing structure of exports and imports has affected the demand for workers with different levels of education in the United States are Katz and Murphy (1992), Murphy and Welch (1992), and Borjas and Ramey (1992). ${ }^{22}$ Their results are discussed below and summarized in Table 5. Katz and Murphy investigate shifts in the relative demand for different types of workers between 1963 to 1987 by estimating the 
direct amount of labor of different educational levels embodied in U.S. exports and imports for 21 manufacturing industries. They conclude that the effect of trade on the relative demand for different types of labor was quite moderate until large U.S. trade deficits developed in the 1980s. Between 1979 and 1985, trade changes increased the relative demand for male college graduates by .55 percent, while reducing the relative demand for males who dropped out of school with 8-11 years of education by .63 percent. The changes for female workers were 1.26 percent and -2.22 percent, respectively. The authors' estimates of changes in relative labor demand between 1979 and 1987 (they do not give equivalent figures for 1979-1985) due to all factors was +7.2 percent for male workers with a college education and -8.9 percent for males workers who dropped out with 8-11 years of education. Consequently, their estimates suggest that trade changes were not a major factor affecting the demand for U.S. labor, even in the 1980 s. The authors also observe that trade-induced changes in relative labor demands were quite small relative to the increases in the supplies of more-educated workers during the same period.

A fundamental problem with the Katz-Murphy analysis is, as Leamer (1994) points out, that changes in the relative demand for various categories of labor need not have any effect on the relative wages of these types of labor. In the Heckscher-Ohlin trade model, changes in relative factor prices take place only as product prices change, if the state of technology is held constant (see Deardorff and Hakura, 1993). If the prices of internationally traded goods remain fixed (either because the country is so small that it has no affect on its terms of trade or domestic forces tending to shift international prices in a particular direction are offset by foreign economic forces), relative factor prices will remain unchanged. Thus, 
there is no necessary relationship between the factor content of trade and changes in relative factor prices.

Murphy and Welch (1991) analyze how changes in the U.S. net trade deficit for durable goods, nondurable goods, traded services, and nontraded goods as a percent of GNP affect the demand for labor (at given wages) between 1979 and 1986, using a macroeconomic framework in which the industrial structure of U.S. demand remains fixed as well as U.S. technology and factor endowments. They find that the increase in the net trade deficit for the durable goods sector, where the ratio of workers with 12 or fewer years of education to those with 13 or more years is relatively high compared to nontraded goods and traded services, is especially important in explaining the observed shifts in the relative demands for these categories of workers. Arguing that changes in relative wages are likely to be roughly proportional to these demand shifts, they find that the order of actual changes in wages is the same as their predicted order of employment changes. However, while shifts in trading patterns are consistent with the direction of observed changes in relative wages, the actual divergence in relative wages was considerably greater than predicted by their model. For example, they point out that the actual changes in the wages of workers with 12 and 13-15 years of education were $-7.80 \%$ and $-0.33 \%$, respectively, between 1979 and 1986 , whereas the predicted changes due to trade are only $-1.25 \%$ and $-0.36 \%$, respectively.

As the authors note, a key assumption in their approach is that any increase in domestic spending at fixed prices is divided among the various groups of goods and services in a manner that keeps spending shares by sector constant. However, if the desired percentage increase in spending on durable goods was more than the increased spending 
associated with the overall trade deficit's share of GNP, namely, $4.1 \%$, the decrease in the demand for domestic labor in that sector predicted by their model would be reduced. Their assumptions imply that any increase in sector spending beyond the overall deficit has to be due to a decline in the price of the sector's products brought about by increased foreign competition. Thus, with a decline in relative prices, the relative wages of the factor used intensively in producing these products must decline. The appropriate sectoral marginal propensities to spend out of the increased domestic expenditures associated with a particular overall trade deficit are empirical issues that should be determined when using such a model.

Borjas and Ramey (1993) argue that foreign competition in highly concentrated manufacturing industries was an important factor underlying the increase in the returns to skills observed during the 1980s. They present a model of wage determination in which one sector, which uses only low-skill labor, is organized oligopolistically. Firms in the rest of the economy use both low-skill and high-skill labor and operate in perfectly competitive markets. The low-skill workers in the oligopolistic sector share in the excess profits of this industry and thus earn rents that raise their wages above low-skill workers in the competitive sector. Increased import competition reduces these rents significantly and also leads to a reduction in the number of workers employed in the durable goods sector. These extra workers shift to the competitive sector and drive down the wage of low-skill workers in that sector too.

Borjas and Ramey utilize industry data for major metropolitan areas in the United States to test their theory. They first regress the wage differential between college graduates and high-school dropouts on the fraction of the labor force in highly concentrated, importcompeting industries producing durable goods, the fraction of the labor force in low- 
concentration import industries and such factors as the fraction of the population foreign-born, the fraction of women in the labor force, and the unemployment rate. As expected, they find that high-school dropouts fare better relative to college graduates the greater the proportion of workers employed in highly concentrated import-competing industries. Borjas and Ramey then utilize these regressions to estimate the proportion of the actual change in this wage gap between 1976 and 1990 that can be explained by changes in the variables, e.g., the decline in the fraction of the labor force employed in highly concentrated import-competing industries. They find that about 12 percent of the decrease in the wages of high-school drop outs relative to college graduates can be accounted for by the decline in the importance of these concentrated, import-sensitive sectors. (These industries accounted for 4.3 percent of the workforce in 1976.) The increase in the proportion of foreign-born workers explains 14 percent of the increase in the wage gap, while the greater female labor force participation rate accounts for 25 percent of the widening of the wage gap. The effect of the change in the unemployment rate is neglible. This leaves about 48 percent of the observed change in the wages of high school drop outs relative to the wages of college graduates due to unexplained factors.

Recently, Krugman and Lawrence (1993) (also see Lawrence and Slaughter, 1993) have argued that increased import competition of the type discussed by the above three groups of authors cannot be more than a "quantitatively minor" (ibid, Abstract) part of the explanation of the growing wage gap in the United States between better and less welleducated workers, i.e., between more skilled and less skilled workers, in the 1980 s. Under the standard Heckscher-Ohlin two-good, two-factor, two-country trade model with given 
factor endowments and identical technologies in both countries, the effects of increased import competition on the home country, specifically an increase in the ratio of its imports to its output of the import good as a consequence of a relative lowering of foreign production costs for the good, are as follows. ${ }^{23}$ First, assume, as the data indicate, that the import sector uses a higher proportion of less skilled to more skilled workers (the only factors of production) than does the export sector. As the relative price of the import good decreases and imports increase, the real wages of the less skilled workers will fall and the real wages of the more skilled workers will rise. This is the Stolper-Samuelson (1941) relationship.

If less skilled labor can be substituted for more skilled labor in producing a given output level of the two goods, the decline in the wages of less skilled to more skilled workers will lead to the substitution of less skilled for more skilled workers in producing both goods, thereby raising the ratio of less skilled to more skilled workers in both industries. Output and employment also decline in the unskilled labor-intensive industry and expand in the skillintensive industry in response to the decline in the price of the good produced by the unskilled labor-intensive sectors relative to the good produced by skilled labor.

These points are demonstrated in Figures $2 a$ and $2 b$, which depict the effect of increased foreign competitiveness in the standard two-good, two-factor Heckscher-Ohlin trade model. The effect of increased foreign competitiveness is to lower the price of the good exported by foreigners, assumed to be the unskilled labor-intensive good, X. This causes production of this good to decrease in the home country, e.g., the United States, and resources to be shifted to the production of the skilled labor-intensive good. This is shown in Figure 2a, which depicts the production possibilities curve of the home country, by the shift 
in the production point from $o_{1}$ to $o_{2}$ and in the consumption point from $c_{1}$ to $c_{2}$.

Both the between-industry and within-industry shifts in the home country's fixed endowments of unskilled and skilled labor that accompany this change in production are shown in Figure 2b. As the output of good $\mathrm{X}$ declines in response to its lower price, both unskilled and skilled labor are moved from the production of $\mathrm{X}$ to the production of $\mathrm{Y}$. However, since the production of good $\mathrm{Y}$ requires relatively less unskilled labor than the production of good $\mathrm{X}$, the wages of unskilled labor decline relative to the wages of skilled labor. This induces producers of both $\mathrm{X}$ and $\mathrm{Y}$ to decrease the ratio of skilled to unskilled labor used to produce these goods. In other words, as the production of $\mathrm{Y}$ increases and $\mathrm{X}$ decreases, the labor allocation point moves from $o_{1}$ to $o_{2}$ in Figure 2b, and the ratio of skilled to unskilled labor used in production decreases for both goods.

Krugman and Lawrence argue that observed trends in the United States during the 1980s are inconsistent with this scenario. First, the average ratio of unskilled to skilled workers used in producing goods and services did not rise; instead, it fell significantly. They also claim that the skill-intensive industries showed no tendency to grow faster than unskilled labor-intensive industries. (As explained later in this section, this claim appears to be incorrect.) Thus, they conclude that increased import competition could not have been an important factor in accounting for the widening wage gap in the 1980s. Their preferred explanation for the observed wage change is that domestic technological change increased the demand for more-skilled workers compared to less-skilled workers. Lawrence and Slaughter (1993) specifically mention unskilled labor-saving technological progress, such as that associated with the greater use of computers, as a possible explanation of the relative wages 
shift in the 1980s. However, they do not spell out just how this type of technological progress could lead to the observed shifts in the use of skilled to unskilled labor in most industries as well as in the ratio of the output of skilled labor-intensive industries to the output of unskilled labor-intensive sectors and in the terms of trade of the United States.

Leamer (1994) criticizes the failure by Krugman and Lawrence to provide an analytical background to their statement that less skilled-saving technological progress is a likely explanation for the observed increased wage inequality. As Leamer rightly points out, the effects of such progress depend crucially in which sector such technological progress takes place. For example, in the two-good, two-factor Heckscher-Ohlin model outlined above, technical progress confined to the skilled labor-intensive export sector that saves on unskilled labor has the effect of raising the wages of more skilled labor compared to less skilled labor without any change in product prices. However, while the ratio of the use of more skilled to less skilled labor may end up higher in the export sector even after the substitution of less skilled for more skilled labor in response to this factor price change, it will decline in the import sector if factor substitution is possible, an outcome that is not consistent with the observed rise in the ratio of more skilled to less skilled workers in almost all industries. Such technological change in a country exporting skill-intensive goods also increases the output of the skilled labor-intensive good relative to the unskilled labor-intensive good and thus, by tending to decrease the international price of skilled labor-intensive goods, leads to a decline in the country's terms of trade. However, the terms of trade of the United States improved somewhat iin the first half of the 1980s.

As explained in the discussion in Section III of unskilled labor-saving progress (and in 
the Appendix), if this type of technological progress takes place to the same extent in both sectors, the effect prior to any change in relative product prices is to increase the output of the unskilled labor-intensive good relative to the output of the skilled labor-intensive good. This increase in the relative supply of the unskilled labor-intensive good, in turn, tends to bring about a decline in the price of the unskilled labor-intensive good, thereby lowering the wages of unskilled labor relative to skilled labor as well as decreasing the output of unskilled laborintensive goods and increasing the output of the skilled labor-intensive goods. It is possible that this latter output shift could be sufficiently strong to offset the initial shift in the opposite direction so that the country would end up with a higher ratio of the output of skilled laborintensive goods to unskilled labor-intensive goods than initially, higher wages of skilled workers relative to unskilled workers and improved terms of trade, all of which are consistent with what we observe for the 1980s. The decline in the wages of unskilled workers relative to skilled workers leads to the substitution of the latter for the former workers, but this need not be strong enough to offset the initial increase in the use of skilled workers relative to unskilled workers. However, one difficulty with this explanation of what happened in the $1980 \mathrm{~s}$ in the United States is that the volume of trade should decrease with this type of technological progress. (This can be seen from Figure 4A in the Appendix.). However, the volume of U.S. exports increased 58 percent between 1980 and 1990 and the volume of imports by 92 percent. (Real gross national product only rose by 29 percent between these years.)

Futhermore, the fact that the ratio of the output of skilled labor-intensive goods to unskilled labor-intensive goods increased significantly in the 1980s (this ratio increased by 33 
percent in the United States between 1977 and 1987) suggests that it is unlikely that the terms-of-trade improvement by itself brought about the shift in the composition of output toward skilled labor-intensive goods. ${ }^{24}$ The significant increase in the supply of skilled workers relative to unskilled workers was very likely an important factor contributing to this outcome. ${ }^{25}$ Such an endowment change tends to reduce the price of the skilled laborintensive good relative to the unskilled labor-intensive product, that is, worsens the country's terms of trade and reduces the wages of skilled relative to unskilled labor. ${ }^{26}$

This last point is demonstrated with Figures $3 \mathrm{a}$ and $3 \mathrm{~b}$. Figure $3 \mathrm{a}$ shows the initial endowment of the two factors (indicated by the point $O_{Y}$ ) and the initial allocation of the factors in the production of the two goods (indicated by the point $o_{1}$ ). Figure $3 b$ depicts the initial production levels for the two goods, $o_{1}$, at the equilibrium price ratio of good $\mathrm{X}$ for good $\mathrm{Y}$ (the slope of the line $o_{1} c_{1}$ ) and the initial consumption levels, $c_{1}$. Now assume that the supplies of both skilled labor and unskilled labor increase but that the supply of skilled labor increases relatively more. The new endowments of the two factor are shown in Figure $3 a$ as the point $\mathrm{O}_{\mathrm{Y}^{\prime}}$. If the equilibrium prices of the goods remained unchanged, the new allocation of the supplies of the two factors in producting the two goods would have to be at the point $\mathrm{O}_{2}$ in order to maintain full employment of both factors. Since the lengths of the lines from the origins $\mathrm{O}_{\mathrm{X}}$ and $\mathrm{O}_{\mathrm{Y}}$ in Figure $3 a$ to the labor allocation points $\mathrm{o}_{1}$ and $\mathrm{o}_{2}$ indicate the outputs of $\mathrm{X}$ and $\mathrm{Y}$, the output of the skilled labor intensive good $\mathrm{Y}$ would increase relative to the output of the unskilled labor-intensive good X (the output of X actually decreases in the case depicted) as a consequence of the endowment change and unchanged product prices.. The point on the new production possibilities curve where the marginal cost 
of producing $\mathrm{X}$ (the slope of the production possibilities curve) is the same as at the initial equilibrium production point is $\mathrm{o}_{2}$ in Figure $3 \mathrm{~b}$. With homothetic preferences, the increase in the production of $\mathrm{Y}$ relative to the production of $\mathrm{X}$ implies that the country's offer of $\mathrm{Y}$ for $\mathrm{X}$ at the initial equilibrium price will be greater from the point $\mathrm{o}_{2}$ than from the initial production point $o_{1}$, i.e., the line $o_{2} c_{2}$ is longer than the line $o_{1} c_{1}$. Since this relationship holds for all prices at which the country will offer $Y$ for $X$, it means that the country's offer curve has shifted outward and that, with a given foreign offer curve of $\mathrm{Y}$ for $\mathrm{X}$, the equilibrium relative price of $\mathrm{Y}$ will decrease (the relative price of $\mathrm{X}$ will increase). Assuming the new equilibrium price of $X$ to equal the slope of the line $o_{3} c_{3}$, the new equilibrium production point will be $o_{3}$ in Figure $3 b$, while the new consumption equilibrium point will be $c_{3}$. The allocation of the two factors in producing the two goods is shown in Figure $3 a$ as $o_{3}$. Since the relative price of $\mathrm{X}$, the unskilled labor-intensive good has risen, the wages of unskilled labor rise relative to the wages of skilled labor, and the ratio of skilled to unskilled labor used in producing each good increases..

Thus, once the increase in the supply of skilled relative to unskilled labor is introduced into the analysis, the Krugman-Lawrence explanation of unskilled labor-saving technical progress that is equal across all industries appears to be inadequate to account for the observed economic changes in the United States during the 1980s. The combination of these two factors tends to yield an outcome of worsened terms-of-trade and decreased wages of skilled labor relative to unskilled labor.

If, however, the unskilled labor-saving technical progress is greater in the skilled labor-intensive sector, the wages of skilled labor will rise relative to those of unskilled labor 
with unchanged terms of trade, and this wage ratio could end up being higher than initially, even if the relative price of the skilled labor-intensive good falls somewhat. ${ }^{27}$ It is still necessary to introduce increased foreign competition in unskilled labor-intensive goods to explain the observed terms-of-trade improvement in the early $1980 \mathrm{~s}$, but the increase in skilled workers' wages is now due partly to the more rapid technical progress in the skilled labor-intensive sector and partly to the fall in the price of the unskilled labor-intensive good due to increased foreign competition. Without detailed knowledge about the responsiveness of relative wages to these two factors, one cannot say just how important the foreign factor is in raising the relative wages of skilled workers. However, on the basis of the preceding analysis, the conclusion by Krugman and Lawrence that increased foreign competition, due, for example, to the appreciation of the U.S. dollar in the early 1980 s, cannot be more than a "quantitatively minor" part of the explanation for the increased U.S. wage gap during the 1980 s does not appear to be warranted.

\section{Conclusions}

Recent analyses of the employment impact of changes in patterns of international trade are broadly consistent with those undertaken in the late 1970 s and early 1980 s. The most comprehensive and detailed study to date (OECD, 1992b) shows, as earlier studies had, that domestic factors, such as changes in demand for domestic goods and increases in labor productivity have generally been much more important in accounting for changes in total domestic employment than changes in demand for imports. Furthermore, in the countries and periods covered in this study, the employment-creating effects of increased exports usually dominated the employment-displacing effects of increased imports. 
Some have argued that the productivity increases have themselves been brought about by the increased import competition. While this argument cannot be rejected, neither existing endogenous growth models nor what empirical evidence is available on the subject seem to support this conclusion.

Consistent with earlier investigations, the OECD study does find, however, that increased imports were a major factor in accounting for employment declines in particular low-technology industries, such as textiles, clothing, footwear, ferrous metals, wood and furniture, and food, drink and tobacco.

There is still considerable divergence in views among economists about the employment effects of foreign direct investment (see Pugel, 1985). One key issue is the extent to which direct investment abroad substitutes for investment at home. Another is the extent to which foreign direct investment stimulates increases of exports of intermediate goods as well as capital goods. Still another concerns the matter of whether the direct investment involves the construction of new plants or simply the acquisition of existing facilities. It appears that we need more case studies of the actual investment experiences of various firms and industries in different countries before we can make substantial progress in better understanding the employment effects of foreign direct investment.

The recent increase in a number of OECD countries of the wages of college-educated workers relative to those with no more than a high school education has raised new concerns about the effects of trade on the distribution of income. Some have argued that the large U.S. trade deficits of the 1980s contributed significantly to the widening of this wage gap. Most investigators emphasize the role of unskilled labor-saving technical change is explaining this 
outcome. U.S. evidence concerning the greater use of skilled compared with unskilled labor within almost all industries is not consistent with the hypothesis that increased foreign competition in unskilled labor-intensive products is the main reason for the growing wage gap. However, similar to the conclusion reached concerning the employment impact of trade, it does not seem appropriate to dismiss increased foreign competition as an inconsequential factor. But further studies are needed to determine just how important increased foreign competition has been in accounting for observed changes in relative wages.. 


\section{APPENDIX}

The Effects of Unskilled Labor-Saving Technological Progress That is the Same in Both $\underline{\text { Sectors }}$

The effect of this type of technological progress can be illustrated with Figures A1, $\mathrm{A} 2, \mathrm{~A} 3$ and $\mathrm{A} 4$. In Figure $\mathrm{A} 1,1 / \mathrm{p}_{\mathrm{y}}$ and $1 / \mathrm{p}_{\mathrm{x}}$ are unit-value isoquants of the two goods at the initial equilibrium prices ( $p_{Y}$ and $p_{X}$ are the initial equilibrium prices of goods $Y$ and $X$ ), while the line $\mathrm{AB}$ is a unit-value outlay line. In the initial competitive equilibrium, prices equal unit costs for the two goods so that the unit-value outlay line is tangent to both unitvalue isoquants. The slope of $\mathrm{AB}$ indicates the ratio of the wages of skilled to unskilled labor. The slopes of the lines from the origin to the tangency points indicate the ratios of skilled to unskilled labor used in producing each good. These slopes are also shown in Figure A2 (with the skilled to unskilled labor ratio for good $Y$ being measured from $O_{Y}$ ), where the total amounts of skilled and unskilled labor used in producing each good are indicated by the point $o_{1}$. The outputs of the two goods are shown in Figure A3, which depicts the home country's production possibilities curve, as point $o_{1}$. The country trades along the equilibrium international price line, $o_{1} c_{1}$ to the equilibrium consumption point, $c_{1}$. This equilibrium price is determined by the intersection of the home country's offer curve of good $\mathrm{Y}$ for good $\mathrm{X}$ and the foreign country's offer curve of good $\mathrm{X}$ for good $\mathrm{Y}$, which are shown in Figure A4. The slope of the line $\mathrm{Oe}_{1}$ in Figure 4A indicates the initial equilibrium international price of good $\mathrm{X}$.

Unskilled labor-saving technical progress in both goods will pull the unit-value isoquants in Figure A1 toward the origin of the Figure (with unchanged product prices, the 
same output values can be produced with less skilled and unskilled labor) and change the tangency point with an equal-outlay line in a manner such that the ratio of skilled to unskilled labor used in producing each good increases. Since it is assumed that the extent of this technical progress is the same in both goods, with unchanged product prices, the ratio of the wages of skilled labor to the wages of unskilled labor (the slope of the equal-outlay line, $C D$ ) does not change from its initial equilibrium level. The point $\mathrm{o}_{2}$ in Figure $\mathrm{A} 2$ shows how the fixed quantities of unskilled and skilled labor would have to be reallocated between the two goods at the new skilled /unskilled labor production ratios and the initial equilibrium product prices in order to maintain full employment of the two factors. As can be seen from Figure A2, the output of the unskilled labor-intensive good, $X$, would have to increase relatively more than the output of the skilled labor-intensive good, Y (the output of Y could even decrease). The point, $\mathrm{o}_{2}$ in Figure A3, depicts the outputs of the two goods at the point on the new production possibilities curve at which the slope of the new production possibilities curve is the same as the initial one at output point, $o_{1}$. Since the ouput of good $\mathrm{X}$ has increased more than the output of good Y, the home country's offer of good X for good Y at the initial equilibrium price ratio is likely to decrease or, put differently, its international demand for $\mathrm{X}$ at this price is likely to decrease, since its supply of $\mathrm{X}$ increases in relative terms, i.e., the length of the line $o_{2} c_{2}$ is less than the length of $o_{1} c_{1}{ }^{28}$ This pulls the home country's offer curve inward toward the origin of Figure A4, which, in turn, causes the new equilibrium price of the unskilled labor-intensive good, $\mathrm{X}$, (the slope of a line between $\mathrm{O}$ and $e_{2}$ in Figure A4) to fall relative to the price of the skilled labor-intensive good, $Y$.

The decline in the relative price of the unskilled labor-intensive good brings about a 
decrease in the production of this good and increase in the production of the skilled laborintensive good, a decline in the wages of unskilled relative to skilled labor, and a change in the ratio of skilled to unskilled labor used in producing both goods. The new production equilibrium is depicted by the point, $o_{3}$, in Figure $\mathrm{A} 3$, while the new ratios of skilled to unskilled labor used in producing the two goods are shown in Figure A2 by the slope of a line between $\mathrm{O}_{\mathrm{x}}$ and $\mathrm{o}_{3}$ (not drawn) and the reciprocal of the slope of a line (not drawn) between $o_{3}$ and $O_{Y}$. The decrease in the relative price of the unskilled labor-intensive good and the decline in the relative wages of unskilled workers are depicted in Figure Al by the increase in the unit value isoquant $1 / \mathrm{p}_{\mathrm{x}}$ to $1 / \mathrm{p}_{\mathrm{x}}$, (more of both factors are required to produce a dollar's worth of good X when its price falls) and by the shift in the equal outlay line from DC to EF. The decreased slope of EF compared with DC indicates that the relative wages of skilled labor have risen. Thus, there has been a between-industry shift in the use of skilled versus unskilled labor, since relatively more of the skilled labor-intensive good is produced (this is not a necessary outcome), as well as a within-industry shift in the use of the two factors (a higher ratio of skilled labor to unskilled labor is used in producing both goods than initially). 


\section{ENDNOTES}

1. This information and the other data in this section are from OECD (1992a, 1993a).

2. See, for example, $\operatorname{OECD}(1979,1985)$.

3. An implication of the factor proportions theory is that relative factor prices will be completely equalized through trade under such special conditions as identical production functions in all countries, constant returns to scale, no trade barriers, and incomplete specialization.

4. As noted in endnote 2, the OECD carried out two earlier studies.

5. Besides the sources cited in footnote 2, see Schumacher (1984).

6. OECD, (1992b).

7. The figures for Australia are omitted from the table, since OECD researchers believe their estimates for this country are not reliable.

8. For a more detailed discussion of some of these criticisms, see OECD (1979, Annex II).

9. This criticism has, of course, been made before. See, for example, Sapir and Schumacher (1985).

10. As Wood (1991) points out, one way to investigate the importance of noncompeting manufactured goods is to compare matched sets of trade and production data. He argues, however, that the level of detail currently available on the basis of the Standard International Industrial Classification is too broad to be useful for this purpose. But other classification systems exist that provide greater detail. For example, there are some 1,500 5-digit product classes in the U.S. Standard Industrial Classification that are comparable to import and export data. Furthermore, under the new Harmonized Description and Coding System (HS) that most countries have now adopted, it is possible to compare trade among countries for approximately 5,500 products.

11. See Trefler (1993) for a recent contribution on this subject.

12. They should also be corrected for the general productivity increase that has taken place in the interval, but it would be interesting to compare Wood's calculation with these, even without this latter modification. 
13. If the within-industry component for imports and exports is combined with the betweenindustry component for imports and exports, the combined contribution is still only 11 percent of the annual rise in the share of nonproduction workers.

14. This follows from the Stolper-Samuelson theorem, which is a basic relationship used in trade models.

15. These ratios can both decrease even though the country's total endowments of skilled and unskilled labor remain fixed, since the country's endowment ratio of skilled to unskilled labor is a weighted average of the ratio of skilled to unskilled labor used in producing each good, where the weights are the proportion of the total supply of unskilled labor used in the production of each good (see Stolper and Samuelson, 1941).

16. In a two-factor, two-good model, the output of the unskilled labor-intensive good must increase relatively more than the skilled labor-intensive good at given prices for the two goods in order to fully employ the available endowment of unskilled labor.

17. A good illustration of this effect is the U.S. export surplus with Mexico that has developed in recent years as U.S. direct investment in Mexico has increased sharply.

18. According to the OECD (1992b) study discussed in the trade section above, the average annual absolute level of job losses in the United States between 1977 and 1985 due to increased imports was 219,000 .

19. Since U.S. nonagricultural employment increased by 10.3 million between 1982 and 1986, this increase amounts to 5.3 percent of the increase in employment over the period. It should also be noted that this figure does not include any of the employment generated from supplying intermediate inputs.

20. The employment figures for the United Kingdom were not subdivided into unskilled and skilled workers.

21. There is insufficient analysis to draw conclusions about other industrial countries.

22. There do not seem to be any studies of how the shifts in the pattern of U.S. direct foreign investment and direct foreign investment in the United States have affected relative wages.

23. It should be noted that the increased ability of foreigner to compete in the home country can be due to such different factors as a relative increase in the endowment of unskilled labor aboad, technological progress in the foreign unskilled labor-intensive sector, and appreciation of the home country's currency as a consequence of its macroeconomic policies.

24. To calculate these percentages, workers were classified as skilled or unskilled workers depending on their level of education (unskilled workers being those with 12 years or less of education and skilled workers those with above 12 years of education) and all industries then divided into those producing skilled labor-intensive goods and unskilled labor-intensive goods 
on the basis of whether the ratio of skilled to unskilled workers in an industry was above or below the median of this ratio for all industries (see Baldwin and Cain, 1994). As Leamer notes, by basing their division of workers into skilled versus unskilled workers on whether the workers are production (supposedly unskilled workers) versus nonproduction workers (supposedly skilled workers), Krugman and Lawrence do not appear to separate the two types of workers adequately.

25 . In the period from 1977 to 1987 , the ratio of the supply of skilled workers to the supply of unskilled workers ( as defined in endnote 24) increased 34 percent.

26. The rapid increase in the supply of skilled relative to unskilled labor in the 1970 s seems to the main explanation for the decline in the ratio of the wages of skilled to unskilled labor in this period. Between 1967 and 1977, for example, this ratio fell from 1.45 to 1.35.

27. See Figure A1 in the Appendix for an illustration of this type of technological progress.

28. Homothetic preferences are assumed. Consequently, the consumption ratio for the two goods stays the same as income increases but the price remains unchanged. 


\section{REFERENCES}

Baldwin, Robert E. and Glen G.. Cain (1994), "Trade and U.S. Relative Wages: Some Preliminary Results," National Bureau of Economic Research, Summer Institute paper.

Barro, Robert J. (1991), "Economic Growth in a Cross Section of Countries," Quarterly Journal of Economics, 106, 407-443.

Bergsten, C. Fred, Thomas Horst and Theodore Moran (1978), American Multinationals and American Interests, Washington, D.C.: The Brookings Institution.

Berman, Eli, John Bound and Zvi Griliches (1994), "Changes in the Demand for Skilled Labor within U.S. Manufacturing: Evidence from Annual Survey of Manufacturers," Quarterly Journal of Economics, CIX, 2, 367-397.

Borjas, George J. and Valerie A. Ramey (1993), "Foreign Competition, Market Power, and Wage Inequality: Theory and Evidence," National Bureau of Economic Research Working Paper No. 4556.

Bound, John and George Johnson (1992), "Changes in the Structure of Wages in the 1980s: An Evaluation of Alternative Explanations," American Economic Review, 82, 3, June, 371392. 
Caves, Richard and Matthew Krepps (1993), "Fat: The Displacement of Nonproduction Workers from U.S. Manufacturing Industries," in Brookings Papers: Macroeconomics 2, 1993, Washington, D.C.: The Brookings Institution.

Corden, W. M. (1974), Trade Policy and Economic Welfare, Oxford: Clarendon Press.

Davis, Steven J. (1992), "Cross-Country Patterns of Change in Relative Wages," in Oliver Jean Blanchard and Stanley Fischer (eds), NBER Macroeconomics Annual 1992, Cambridge, MA: The MIT Press.

Deardorff, Alan and Dalia Hakura (1993), "Trade and Wages: What are the Questions?," Paper prepared for Seminar on "The Influence of International Trade on Jobs and Wages," September 10, 1993, American Enterprise Institute, Washington, D.C.

Driver, Ciaran, Andrew Kilpatrick and Barry Naisbitt (1988), "The Sensitivity of Estimated Employment Effects in Input-Output Studies: An Example of the Use of Marginal Versus Average Coefficients," Economic Modelling, April, 145-150.

Ethier, Wilfred J. (1984), "Higher Dimensional Issues in Trade Theory," in R.W. Jones and P.B. Kenen (eds.), Handbook of International Economics, Vol. I, pp. 131-184.

Frank, Robert H. and Richard T. Freeman (1978), "The Distributional Consequences of Direct 
Foreign Investment," in William G. Dewald (ed.), The Impact of International Trade and Investment on Employment, Washington, D.C.: U.S. Department of Labor, Bureau of International Labor Affairs.

General Agreement on Tariffs and Trade, International Trade, various years, Geneva: GATT.

Glickman, Norman J. and Douglas P. Woodward (1989), The New Competitors: How Foreign Investors Are Changing the U.S. Economy, New York: Basic Books.

Grossman, Gene M. (1986), "Imports as a Cause of Injury: The Case of the U.S. Steel Industry," Journal of International Economics, XX, 201-223.

Grossman, Gene M. ( 1987), "The Employment and Wage Effects of Import Competition in the United States," Journal of International Integration, 2, 1-23.

International Monetary Fund, World Economic Outlook, May 1990.

Katz, Lawrence F., Gary W. Loveman, and David G. Blanchflower (1992), "A Comparison of Changes in the Structure of Wages in Four OECD Countries," presented at National Bureau of Economic Research Conference on Comparative Labor Markets Project on "Differences and Changes in Wage Structures," Cambridge, MA, July 23-24, 1992. 
Katz, Lawrence F. and Kevin Murphy (1992), "Changes in Relative Wages, 1963-1987:

Supply and Demand Factors," Quarterly Journal of Economics, CVII, February, 36-78.

Krueger, Anne O. (1977), Growth, Distortions, and Patterns of Trade Among Many Countries, Princeton Studies in International Finance No. 40, International Finance Section, Department of Economics, Princeton University.

Krueger, Anne O., Hal B. Lary, Terry Monson, and Narongchai Akrasanee, eds., (1981), Trade and Employment in Developing Countries: Individual Studies, Vol. 1, Chicago: University of Chicago Press.

Krueger, Anne O. (ed.), (1982), Trade and Employment in Developing Countries: Factor Supply and Substitution, Vol. 2, Chicago: University of Chicago Press.

Krueger, Anne O. (1983), Trade and Employment in Developing Countries: Synthesis and Conclusions, Vol. 3, Chicago: University of Chicago Press.

Krugman, Paul and Robert Lawrence (1993), "Trade, Jobs, and Wages," National Bureau of Economics Working Paper No. 4478, September.

Lawrence, Robert Z. and Matthew J. Slaughter (1993), "Trade and U.S. Wages: Great Sucking Sound or Small Hiccup?," Kennedy School of Government, Harvard University. 
Leamer, Edward E. (1994), "Trade, Wages and Revolving Door Ideas,", National Bureau of Economics Working Paper No. 4716, April.

Leibenstein, Harvey (1966), "Allocative Efficiency Versus 'X-Efficiency' ," American Economic Review, 56, 392-415.

Lipsey, Robert E. and Merle Y. Weiss (1981), "Foreign Production and Exports in Manufacturing Industries," Review of Economics and Statistics, 63, 4, November, 488-494.

Mankiw, Gregory, David Romer, and David Weil (1992), "A Contribution to the Empirics of Economic Growth," Quarterly Journal of Economics, 152, 407-437.

Martin, John P. and John M. Evans (1981), "Notes on Measuring the Employment Displacement Effects of Trade by the Accounting Procedure," Oxford Economic Papers, 33, $1,154-164$.

Messerlin, Patrick A. (1994), "The Impact of Trade and Capital Movements on Labor: Evidence on the French Case," Institut d'Etudes Politique de Paris.

Murphy, Kevin and Finis Welch (1991), "The Role of International Trade in Wage Differentials," in M.Kosters (ed.), Workers and Their Wages, Washington, D.C.: American Enterprise Institute 
Oman, Charles (1994), Globalisation and Regionalisation: The Challenge for Developing Countries, Paris: OECD.

OECD (1979), The Impact of the Newly Industrialising Countries on Production and Trade in Manufactures, Report by Secretary-General, Paris: OECD.

OECD (1985), Employment Growth and Structural Change, Paris: OECD.

OECD (1992a), International Direct Investment: Policies and Trends in the 1980s, Paris: OECD.

OECD (1992b), Structural Change and Industrial Performance: A Seven Country Growth Decomposition Study, Paris: OECD.

OECD (1993a), "Recent Developments in Foreign Direct Investment: A Sectoral Analysis," Paris: OECD.

OECD (1993b), Employment Outlook, Paris: OECD.

OECD (1994), The Jobs Study: Facts, Analysis, Strategies, Paris, OECD. 
Pugel, Thomas A. (1985), "The United States," in John H. Dunning, (ed.), Multinational Enterprises, Economic Structure and Industrial Competitiveness, New York: John Wiley and Sons.

Revenga, Ana L. (1992), "Exporting Jobs: The Impact of Import Competition on Employment and Wages in U.S. Manufacturing," Quarterly Journal of Economics, CVII, 1, 255-284.

Rousslang, Donald J. (1978), "Comment on Frank-Freeman Paper," in William G. Dewald (ed.), The Impact of International Trade and Investment on Employment, Washington, D.C.: U.S. Department of Labor, Bureau of International Labor Affairs.

Sapir, Andre and Dieter Schumacher (1985), "The Employment Impact of Shifts in the Composition of Commodity and Services Trade," in Employment Growth and Structural Change, Paris: OECD.

Schumacher, Dieter (1984), "North-South Trade and Shifts in Employment: A Comparative Analysis of Six European Community Countries," International Labour Review, 3, May-June, 333-347.

Stolper, Wolfgang and Paul A. Samuelson (1941), "Protection and Real Wages," Review of 
Economic Studies, IX, 58-73.

Trefler, Daniel (1993), "International Factor Price Differences: Leontief Was Right,!" Journal of Political Economy, 101, 6, 961-987.

U.S. Department of Commerce (1984), "The Input-Output Structure of the U.S. Economy, 1977," Survey of Current Business, 64, 5, May, 42-84.

U.S. Department of Commerce (1988), Survey of Current Business, 68, 4, April, 31-46.

Wells, Louis T., Jr. (1992), "Conflict or Indifference: US Multinationals in a World of Regional Trading Blocs," Organization for Economic Cooperation and Development, Research Programme on Globalisation and Regionalisation, Technical Paper, No. 57, Paris: OECD.

Wood, Adrian (1991), "How Much Does Trade with the South Affect Workers in the North?," The World Bank Research Observer, 6,3, January,19-35.

Wood, Adrian (1994), North-South Trade, Employment and Inequality: Changing Fortunes in a Skill-Driven World, Oxford: Clarendon Press. 
Figure $1 a$.

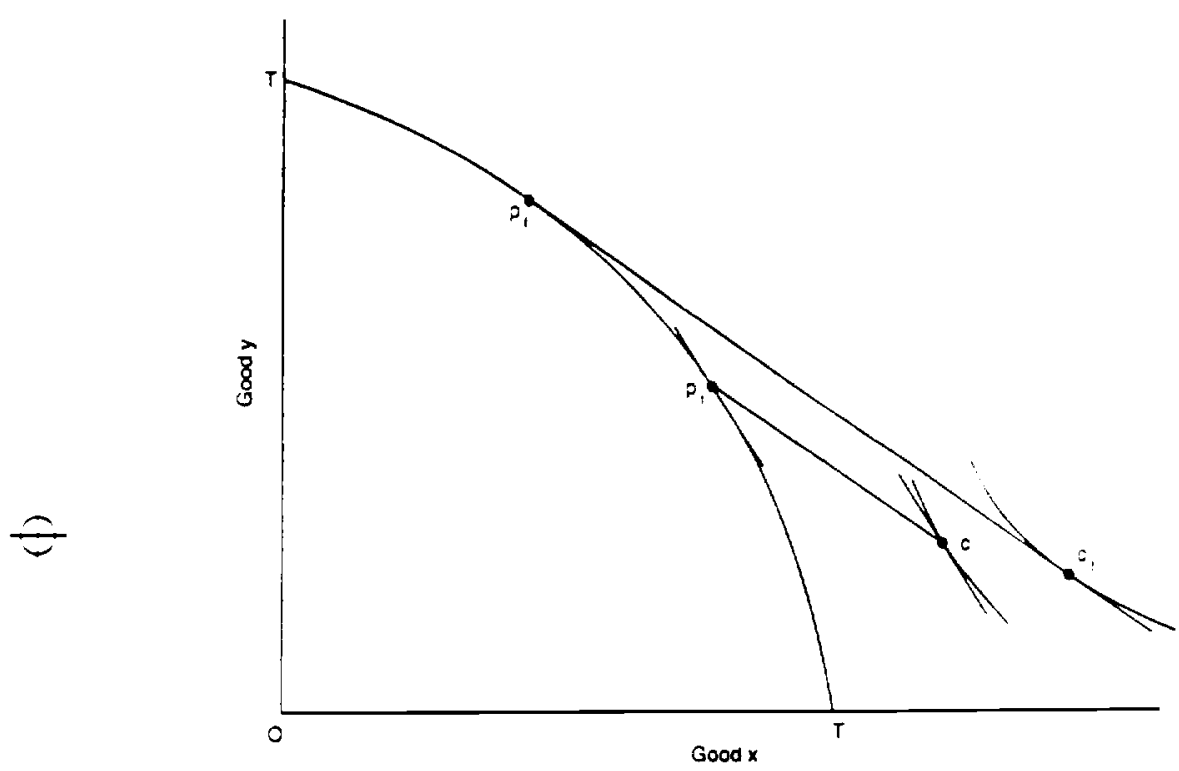

Figure $1 b$.

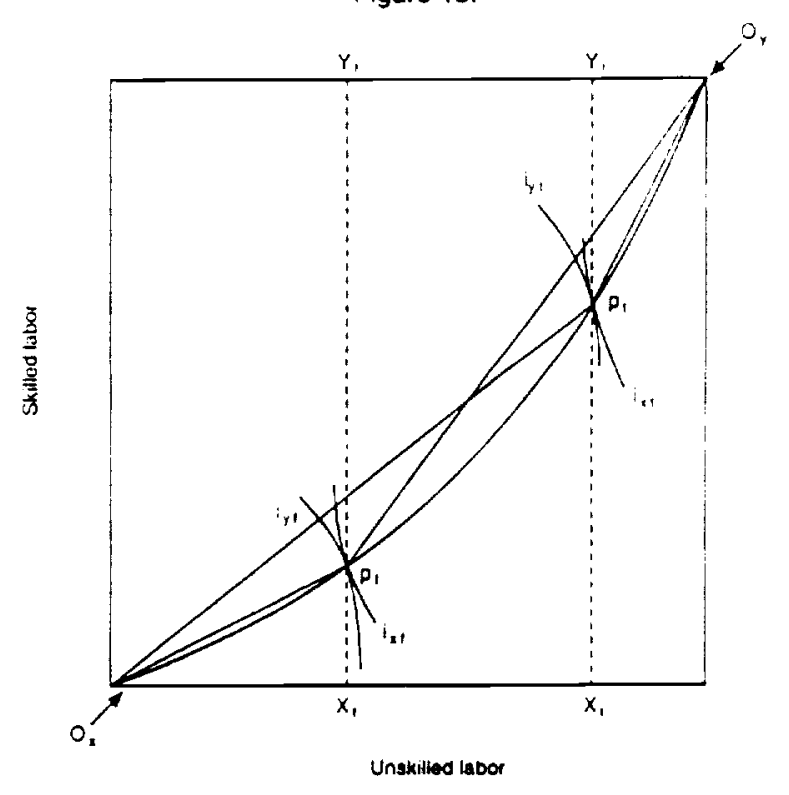


Figure $2 a$.

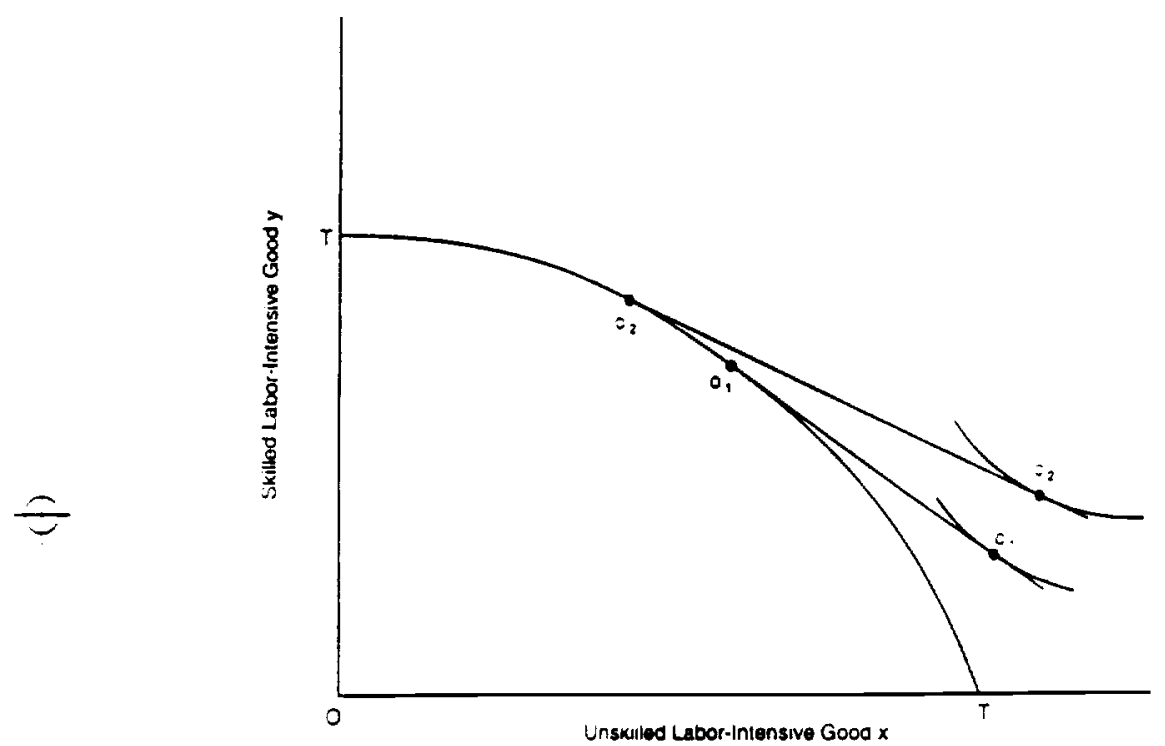

Figure $2 b$.

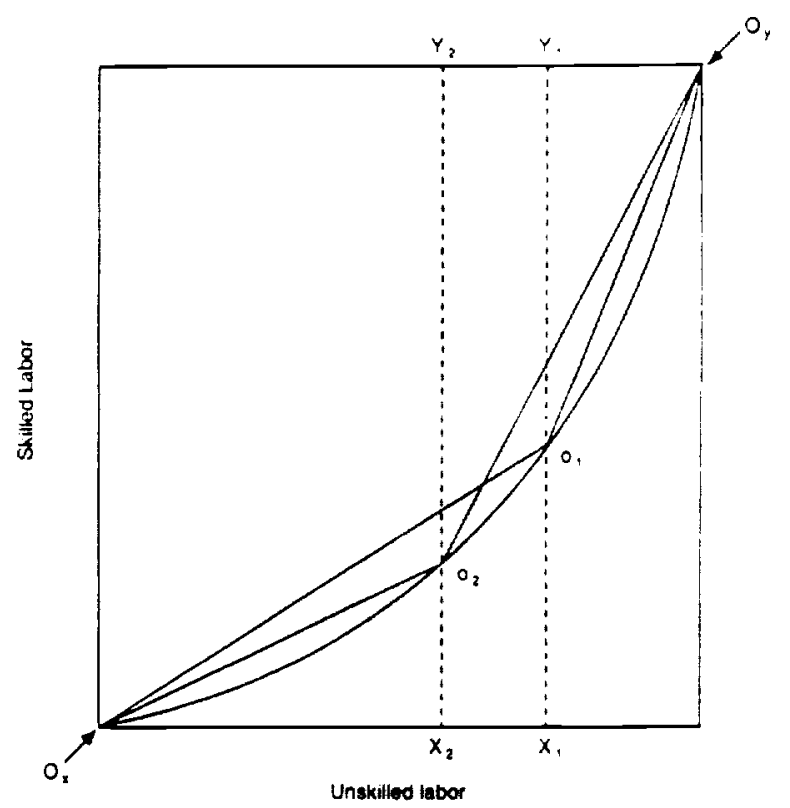


Figure $3 a$.

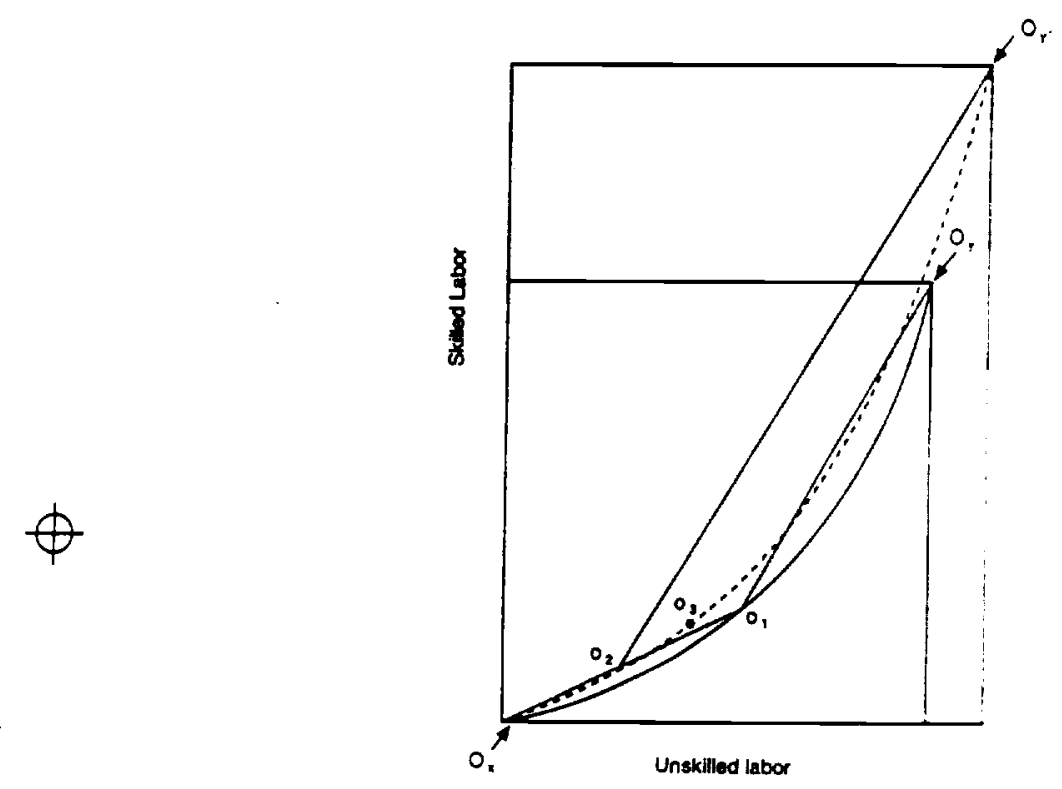

Figure $3 b$.

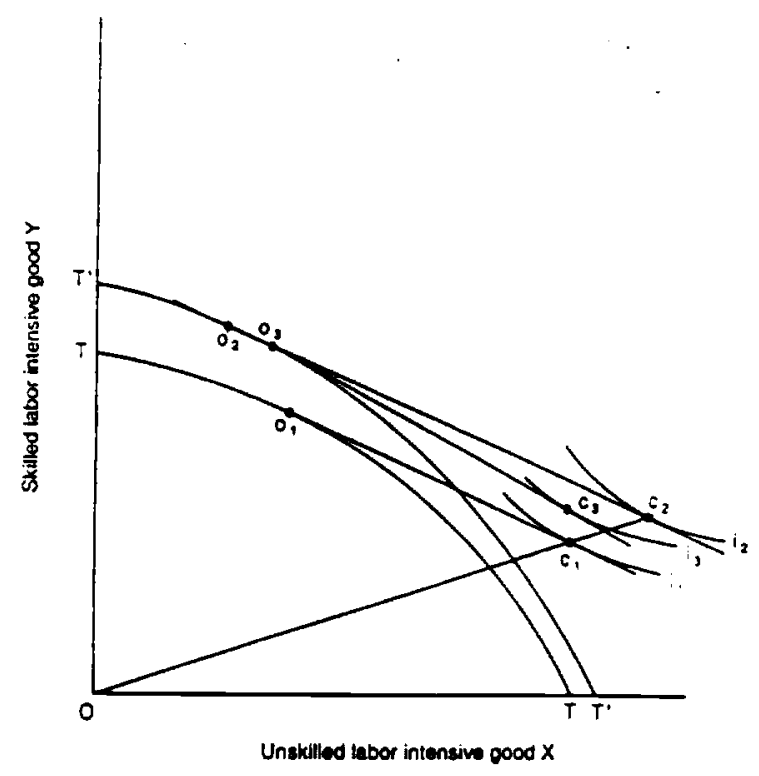


Figure A1.

$\stackrel{1}{ \pm}$

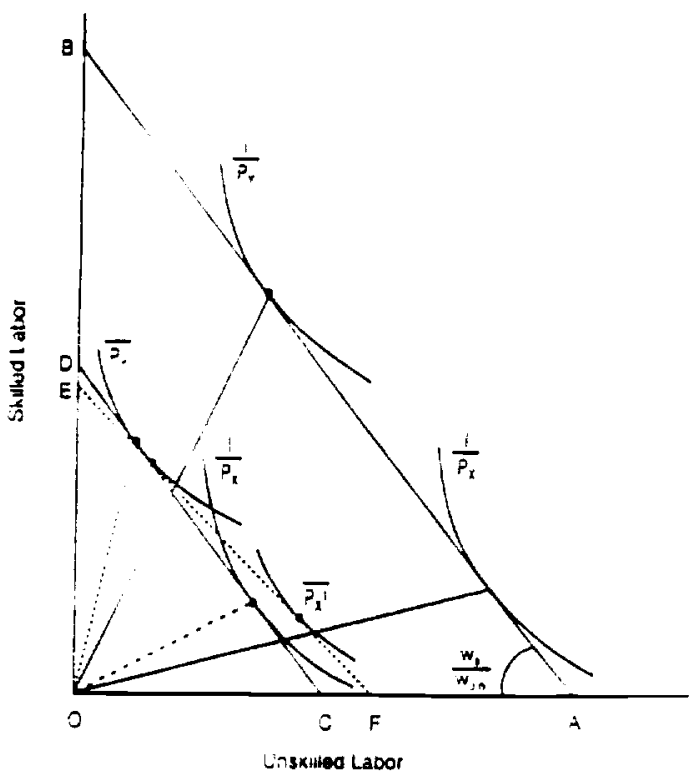

Figure A2.

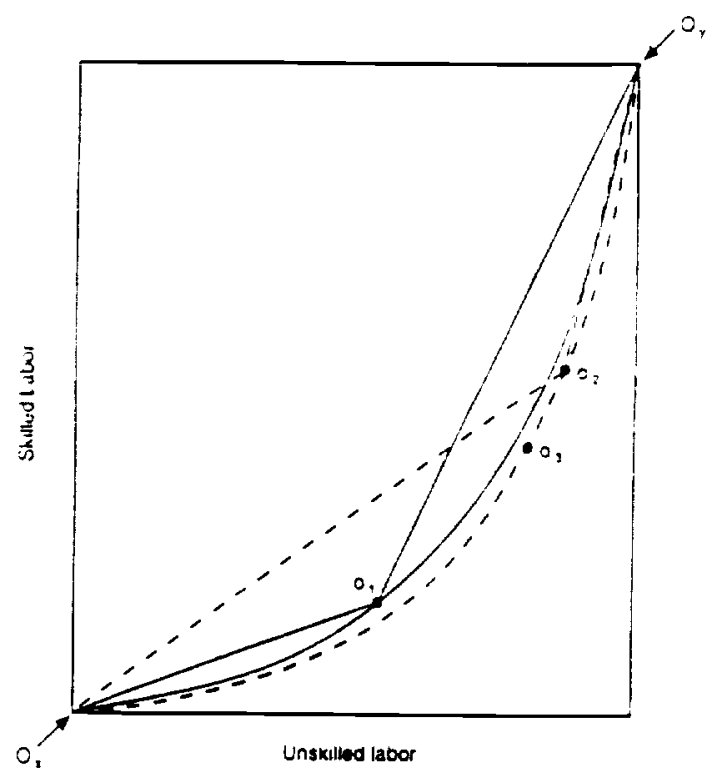


Figure A3.

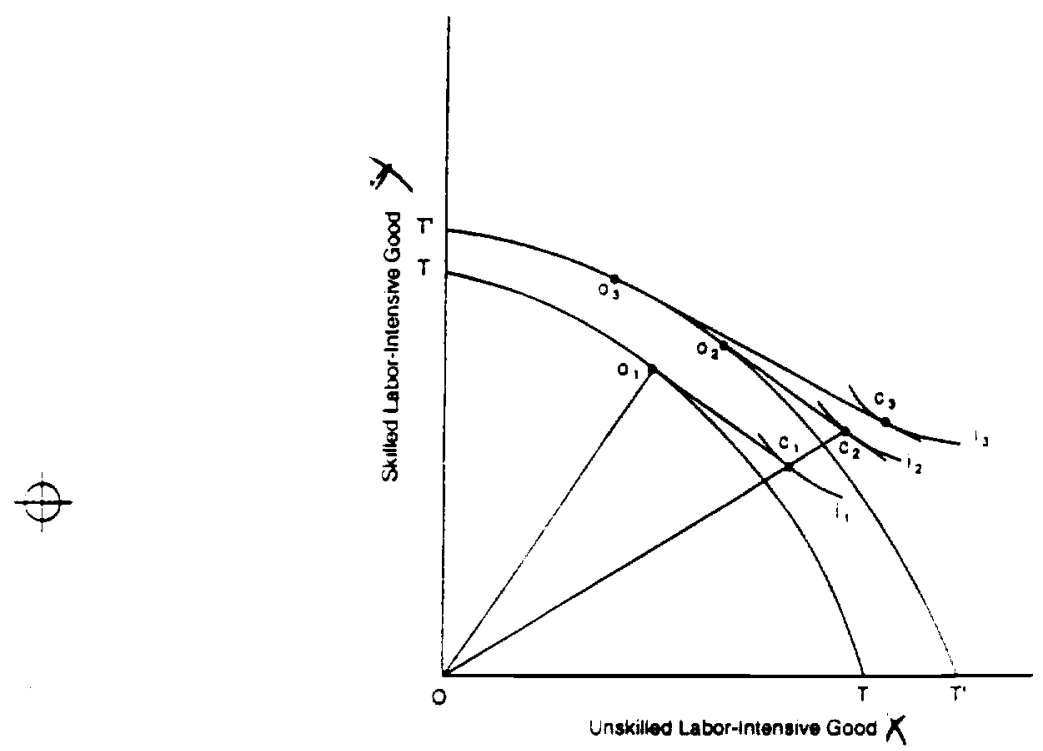

Figure A4.

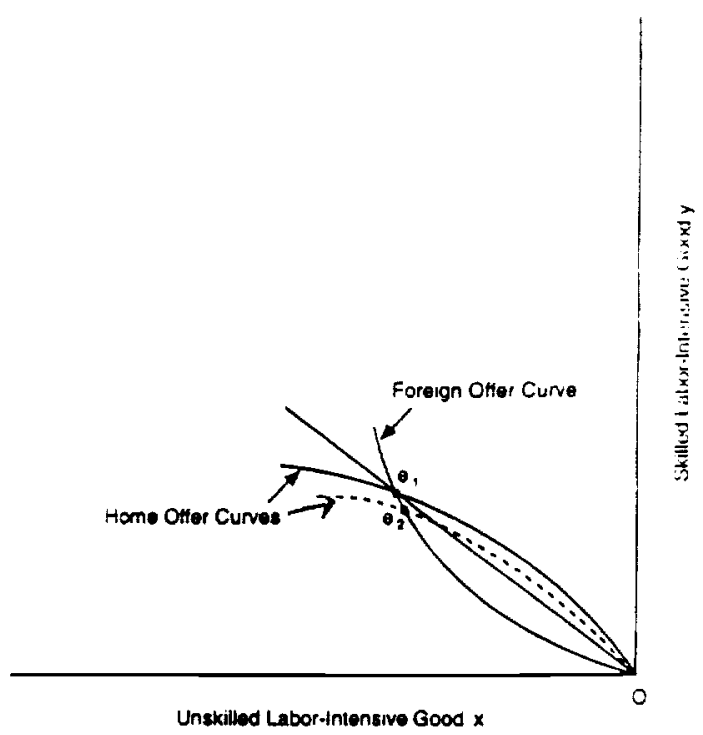

